\title{
UNIÕES PARALELAS \\ E DIREITO DAS SUCESSÕES
}

\author{
Fernando René Graeff ${ }^{1}$
}

\section{INTRODUÇÃO}

O presente trabalho versará sobre as uniões informais ${ }^{2}$ paralelas a um casamento ou a uma união estável, especialmente no que diz respeito ao seu enquadramento jurídico (uniões estáveis propriamente ditas ${ }^{3}$ ou apenas uma das espécies de concubinato $\left.^{4}\right)$ e aos efeitos patrimoniais ${ }^{5}$ delas decorrentes, tendo como foco principal o Direito das Sucessões.

1 Advogado sócio de Silveiro Advogados, onde atua nas áreas de Direito de Família e Sucessões. É especialista em Direito de Família pela Pontifícia Universidade Católica do Rio Grande do Sul (PUCRS) e, atualmente, mestrando na Universidade Federal do Rio Grande do Sul (UFRGS) com linha de pesquisa focada no Direito de Família.

$2 \mathrm{O}$ presente estudo limita-se à análise da possibilidade de uniões informais (entendidas estas como não formalizadas pelo casamento), paralelas a um casamento ou a uma união estável, já que não há possibilidade legal de celebração de dois casamentos simultâneos.

3 Uma das divergências que será abordada é justamente a possibilidade de constituição de uniões paralelas simultâneas ou de união estável por quem está impedido de casar.

4 Nova nomenclatura do antes denominado concubinato impuro.

5 O Direito de Família está subdividido em regras de direito pessoal, de direito protetivo e de direito patrimonial. A existência do concubinato, por si só e isoladamente, não gera (e tampouco impede a geração de) direitos no âmbito do direito pessoal e do direito protetivo de família. Por exemplo: os efeitos jurídicos decorrentes da filiação sempre existirão, seja ela decorrente de uma relação eventual, de um casamento ou de um concubinato. Não é a existência do concubinato que gera tais efeitos, mas, sim, uma garantia constitucional. Nesse sentido: “Talvez nem fosse necessário registrar que, se nascerem filhos de pessoas que estão em relação concubinária, não se discute: todos os direitos, de qualquer natureza, são reconhecidos e conferidos a esses filhos, até por ser uma garantia constitucional” (VELOSO, Zeno. Direito hereditário do cônjuge e do companheiro. São Paulo: Saraiva, 2010, p. 204). 
O estudo desse tema é de extrema relevância, seja em face da evolução histórica das relações familiares até a sua integração com a pós-modernidade $^{6}$ (cujas características são bem delineadas por Erik Jayme ${ }^{7}$ ), seja pela presença cada vez mais reincidente de tais espécies de relações em nossa realidade social, seja, ainda, e principalmente, pela extrema dificuldade de se alcançar uma solução jurídica ideal para o problema ${ }^{8}$ diante dos parâmetros da sociedade atual ${ }^{9}$, o que exige aprofundado e permanente estudo da matéria pelos operadores do direito ${ }^{10}$. Historicamente, a família - célula básica e fundamental da sociedade sempre evoluiu e se moldou ao contexto social em que esteve inserida. Especialmente no Brasil, o conceito de família sofreu substancial modificação nas últimas décadas, acom-

6 "Não se criou, certamente, um modelo de família novo que tenha sido forçadamente imposto aos atores sociais brasileiros, como camisa de força obrigatória, no sentido de mudar costumes e tratos. Ao contrário: foi a própria família que mudou, que alterou sua modelagem, sua constituição, que se adequou ao modus de uma época, que se aperfeiçoou com a integração ao novo século ou à pós-modernidade, como se tem preferido dizer. (HIRONAKA, Giselda Maria Fernandes Novaes (Coord.); TARTUCE, Flávio (Coord.); SIMÃO, José Fernando (Coord). Direito de Família e das Sucessões: temas atuais. São Paulo: Método, 2009, p. 454).

7 Pluralismo, comunicação, narração e retorno dos sentimentos (JAYME, Erik. Direito Internacional Privado e Cultura Pós-Moderna. Tradução de Lisiane Feiten Wingert, revisão de Cláudia Lima Marques. Cadernos do Programa de Pós-Graduação em Direito - PPGDir/UFRGS, Porto Alegre, v. 1, n. 1, mar. 2003. 2. ed., 3. Tiragem, dez. 2004, p. 59-68).

8 "Reconhece-se que o concubinato é questão sensível e difícil, ante os valores monogâmicos majoritários da sociedade brasileira, o que torna sempre controvertida qualquer solução jurídica” (LÔBO, Paulo Luiz Netto. Direito civil: famílias. 4. ed. São Paulo: Saraiva, 2011, p. 188).

9 “A matéria é recheada de conturbações sendo, muitas vezes, motivo até de reações perplexas. Tudo isso porque a discussão remonta a um dos parâmetros sociais de maior carga dogmática, qual seja o ideal da monogamia” (ALMEIDA, Renata Barbosa de; RODRIGUES JÚNIOR, Walsir Edson. Direito Civil: Famílias. Rio de Janeiro: Lumen Juris, 2010, p. 81).

10 “Assim, verifica-se que famílias simultâneas é tema debatido no Direito de Família contemporâneo, ainda que algumas decisões desconsiderem seu reconhecimento. Mesmo para aqueles que, preenchidos os requisitos, advogam em favor desta nova entidade familiar, evidencia-se a necessidade de seu melhor desenvolvimento, em razão da especificidade e complexidade das questões envolvidas" (MATOS, Ana Carla Harmatiuk. Aspectos jurídicos das famílias homossexual, simultânea e recomposta. In: HIRONAKA, op. cit., p. 397). 
panhando os fenômenos e anseios sociais. De uma família patriarcal, constituída exclusivamente pela formalidade do casamento, e que tinha como objetivos fundamentais a procriação e o desenvolvimento econômico, passou-se a uma família marcada pela multiplicidade de formas, constituída por laços de afetividade e com a finalidade precípua de realização de seus entes, os quais assumem novos papéis de destaque no núcleo familiar ${ }^{11}$.

Diante de tal evolução - sacramentada pela Constituição Federal de 1988 -, algumas relações informais existentes desde os primórdios da civilização, mas que até então eram vistas com repúdio e inferioridade pela sociedade, passaram a ser reconhecidas e tuteladas pelo Estado. Nesse contexto, uniões duradouras, públicas e contínuas entre homem e mulher desimpedidos de casar, com objetivo de constituir família, passaram a ser reconhecidas pelo ordenamento jurídi- co como verdadeiras entidades familiares geradoras de efeitos no âmbito do Direito de Família e das Sucessões. Tais uniões, antes chamadas pela doutrina e pela jurisprudência de concubinato puro, foram denominadas pela Constituição Federal e pelo Código Civil de 2002 de união estável.

No entanto, uniões paralelas ao casamento (ou a uma união estável), chamadas pela doutrina e pela jurisprudência de concubinato impuro ou adulterino, e atualmente denominadas simplesmente de concubinato, jamais receberam tratamento legal que lhes tenha atribuído efeitos, cuidando o legislador civilista apenas de diferenciá-las das uniões estáveis.

Nem mesmo as diversas inovações trazidas pelo Código Civil de 2002 na esfera do Direito de Família e das Sucessões foram suficientes para conferir mínimo tratamento legal às relações paralelas, permanecendo, nesse tocante, uma grande lacuna na legislação brasileira.

11 "Porém - e isso sim é certo e merece ser sempre reapresentado e demonstrado, especialmente como tema de nossas constantes e cuidadosas reflexões -, vivemos hoje uma nova configuração familiar, reorganizada em modos e meios diferentes de constituição, reapresentada sob distintos matizes e modelos, revisitada pelo papel desempenhado por cada um de seus membros, reformada quando ao destino que cada um passa a ter dentro do núcleo, exatamente por conta dos novos papéis, tudo isso seguramente importando numa nova dimensão do fenômeno das famílias que não pode ser ignorado, uma vez que ela se oferta sem pudor aos olhos de todos os brasileiros e se impõe como novo retrato, ampliado e colorido, da sociedade em que vivemos" (HIRONAKA, Giselda Maria Fernandes Novaes (Coord.); TARTUCE, Flávio (Coord.); SIMÃO, José Fernando (Coord). Direito de Família e das Sucessões: temas atuais. São Paulo: Método, 2009, p. 453). 
Tal histórica omissão legislativa não impediu, todavia, que, em um contexto social marcado pela pluralidade de formas nas relações afetivas ${ }^{12}$, em que relações sólidas e duradouras dão cada vez mais espaço a relações frágeis alicerçadas em um "amor líquido" ${ }^{13}$, a existência de relações informais paralelas a um casamento ou a uma união estável se tornasse um fato social cada vez mais reincidente.

Como não poderia ser diferente, em um cenário caracterizado pela evolução e pelo alargamento do conceito de entidade familiar, pelos princípios constitucionais que norteiam o Direito de Família e das Sucessões, pelos princípios e costumes ainda enraizados na sociedade brasileira, e pelas lacunas deixadas pelo legislador, é cada vez mais amplo e divergente o debate existente quanto à caracterização de tais espécies de relações como verdadeiras entidades familiares geradoras de efeitos jurídicos patrimoniais no âmbito do Direito de Família e das Sucessões.

Para alguns, é possível que tais relações paralelas constituam uma união estável com todas as características e efeitos dela decorrentes. Para outros, no entanto, tais relações paralelas ao casamento ou a uma união estável devem ser tratadas como concubinato, não geradoras, portanto, de efeitos patrimoniais no âmbito do Direito de Família e das Sucessões.

É em relação a essas divergências, especialmente no âmbito do Direito Sucessório, com seus novos regra-

12 “Com a evolução dos costumes, cujo marco normativo encontra seu maior registro na Constituição da República de 1988, a família deixou sua forma singular e passou a ser plural, isto é, existem várias formas e maneiras de se constituir família” (PEREIRA, Rodrigo da Cunha. Concubinato e união estável. 8. ed., rev. e atual. São Paulo: Saraiva, 2012, p. 21).

13 Termo utilizado pelo sociólogo polonês Zygmunt Bauman. Em entrevista disponível em: <http://macroscopio.blogspot.com.br/2007/07/uma-entrevista-interessante-zygmunt. html>, assim argumenta o autor: "As relações amorosas estão hoje entre os dilemas mais penosos com que precisamos nos confrontar e solucionar. Nestes tempos líquidos, precisamos da ajuda de um companheiro leal, 'até que a morte nos separe', mais do que em qualquer outra época. Mas qualquer coisa 'até a morte’ nos desanima e assusta: não se pode permitir que coisas ou pessoas sejam impedimentos ou nos obriguem a diminuir o ritmo de vida. Compromissos de tempo indeterminado ameaçam frustrar e atrapalhar as mudanças que um futuro desconhecido e imprevisível pode exigir. Mas, sem esse compromisso e a disposição para o autossacrifício em prol do parceiro, não se pode pensar no amor verdadeiro. De facto, é uma contradição sem solução. A esperança ainda que falsa é que a quantidade poderia compensar a qualidade: se cada relacionamento é frágil, então vamos ter tantos relacionamentos quanto forem possíveis.”. 
mentos e nuances, que está centrado o objeto do presente trabalho, o qual tem como escopo demonstrar as posições doutrinárias e os atuais entendimentos da jurisprudência gaúcha e dos Tribunais Superiores acerca do tema.

Inicialmente, será demonstrada a evolução histórica do companheirismo e do conceito de entidade familiar, ambos diretamente relacionados. Em seguida, far-se-á uma abordagem das transformações do Direito Sucessório e de suas atuais perspectivas. Posteriormente, será examinado o tratamento que é dado atualmente às uniões paralelas pela doutrina e pela jurisprudência. Por fim, serão analisados os efeitos jurídicos das uniões informais paralelas no Direito Sucessório.

\section{EVOLUÇÃO DO DIREITO DE FAMÍLIA E DO DIREITO SUCESSÓRIO}

As uniões livres e informais (sejam elas ou não paralelas a um casamento ou a uma união estável) constituem-se forma de relação social que sempre esteve presente na história da humanidade. Tais relações, todavia, foram por muito tempo encobertas pela sociedade e esquecidas pelo Direito, tendo, nos últimos anos, sob as novas perspectivas do Direito de Família, ganhado valorização e relevância no mundo jurídico ${ }^{14}$. Nesse sentido, a fim de se compreender adequadamente quais os efeitos que devem ser atribuídos a tais relações no âmbito do Direito de Família, e, em especial, do Direito Sucessório, é preciso, primeiramente, conhecer a evolução das relações familiares e as inovações legislativas, até se chegar à atual realidade social e jurídica que estamos vivenciando.

\subsection{Transformações nas relações familiares e as uniões informais}

Já antes da consolidação da Babilônia, o costume entre os que margeavam o rio Eufrates era que, ao se receber visitas, ofertava-se hospedagem, comida e as próprias mulheres ${ }^{15}$. Na Babilônia, havia a crença de que as várias modalidades de apetites sexuais estimulavam o espírito artístico, o aumento da prole, a produção, o cultivo e a inteligência.

14 “Afastando-se dos laços formais, são valorizadas as relações de mútua ajuda e afeto, com índices cada vez maiores de uniões não matrimonializadas” (FACHIN, Luiz Edson. Direito de família: elementos críticos à luz do novo código civil brasileiro. 2 . ed. Rio de Janeiro: Renovar, 2003, p. 1).

15 GIORGIS, José Carlos Teixeira. Direito de família contemporâneo. Porto Alegre: Livraria do Advogado Editora, 2010, p. 108. 
Na Grécia Antiga, o concubinato era admitido no sistema poligâmico, e, posteriormente, com a instituição da monogamia por Licurgo e Sólon, as concubinas tornaram-se uma classe à parte.

No Direito Romano, o concubinato representava uma das quatro ${ }^{16}$ formas de união entre pessoas de sexo diferente, sendo, todavia, embora comum e frequente ${ }^{17}$, tratado com inferioridade em relação ao casamento (não havia a affectio maritalis e a honor matrimonii). Embora não fosse proibido e nem atentatório à moral ${ }^{18}$, não era reconhecido como instituto jurídico, ficando restrito a um fato social. Sua primeira regulamentação - ainda que indireta - ocorreu com a ascensão do imperador Otávio Augusto, que, diante de um cenário de confrontos internos e de degradação dos valores morais e das tradições de conduta e comportamento dos cidadãos romanos, tentou resgatar o valor da família patriarcal e da ordem moral. O processo de regulamentação pros- seguiu com Constantino até alcançar a categoria de instituto jurídico com Justiniano.

A Igreja Católica dos primeiros tempos foi tolerante com o concubinato, tendo o Direito Canônico inclusive lhe conferido alguns efeitos limitados, sem, entretanto, institucionalizá-lo. Consta que Santo Agostinho admitiu o batismo da concubina, desde que esta se obrigasse a não deixar o companheiro. Santo Hipólito, por sua vez, negava matrimônio a quem o solicitasse para abandonar a concubina, salvo se por ela fosse traído. E o primeiro Concílio de Toledo - 400 - autorizou o concubinato de caráter perpétuo ${ }^{19}$.

Entretanto, diante da degeneração de uniões desabonadoras - que teria chegado aos conventos e passado a ser praticada pelos próprios reis cristãos -, a Igreja mudou de posição, passando, por longo período, a repudiar o concubinato.

Ainda assim, tolerou-o até 1563, quando o Concílio de Trento expres-

16 As outras três eram justae nuptiae, o sine connubio e o contuberinum (Ibidem. p. 108). 17 “Em Roma, não era diferente. No início do império, o concubinato era comum e frequente, inclusive entre homens de grande moralidade, mas não produzia quaisquer efeitos jurídicos” (PEREIRA, Rodrigo da Cunha. Concubinato e união estável. 8. ed., rev. e atual. São Paulo: Saraiva, 2012, p. 33).

18 CAVALCANTI, Lourival Silva. União estável: a inconstitucionalidade de sua regulamentação. São Paulo: Saraiva, 2003, p. 80.

19 FEITOSA, Maria Luiza Pereira de Alencar Mayer. Concubinato e união estável. Jus Navigandi, Teresina, ano 5, n. 45, 1 set. 2000. Disponível em: <http://jus.com.br/ revista/texto/545>. Acesso em: 3 ago. 2012. 
samente o proibiu, tornando obrigatória a celebração pública e formal do matrimônio e impondo a excomunhão aos concubinos que não se separassem após a terceira advertência. Tal postura, que reforçava a noção do casamento como um dos sete sacramentos, espelhava a reação contra a Reforma Protestante que então ameaçava o poder da Igreja.

Nesse contexto, as Ordenações Filipinas determinaram o cumprimento dos regramentos instituídos pelo Concílio de Trento, exigindo prova do matrimônio mediante certidão paroquial.

No Brasil, as Ordenações Filipinas (século XVI) inicialmente até reconheciam no concubinato puro (entre pessoas desimpedidas) uma forma de casamento de fato que se configurava na circunstância de um homem e uma mulher viverem juntos, o que dava direito à meação dos bens adquiridos na constância da relação. Nada mais era do que a atual união estável.

Ao lado dessa modalidade informal de casamento, as Ordenações atribuíam validade ao casamento religioso e ao contrato particular assinado por duas testemunhas. O casamento civil ainda não era reconhecido.

No entanto, a estreita ligação das Ordenações Filipinas com o repressor Concílio de Trento - reconhecidamente as principais fontes originárias do Direito de Família brasileiro - acabou levando à promulgação do Decreto n. 181/1890, instituidor do casamento civil, o qual deixou de reconhecer efeitos jurídicos às relações informais de afeto, ao casamento religioso e ao casamento por contrato particular.

A Constituição Federal de 1891 também reconheceu efeitos apenas ao casamento civil, princípio este mantido nos textos constitucionais seguintes (de 1937, 1946, 1967 e 1969).

O Código de 1916, igualmente, ignorou as uniões de fato entre pessoas desimpedidas, cuidando exclusivamente de cercar de sanções o concubinato adulterino, no objetivo de resguardar o patrimônio da família regularmente constituída pelo casamento. Por influência da Igreja Católica e do Direito Napoleônico - que preconizava o modelo de família hierarquizada e matrimonializada, calcada na procriação, na formação de mão de obra e na obtenção e transmissão de patrimônio -, o legislador brasileiro via o casamento como a única maneira de formação de uma entidade familiar, negando-se reconhecimento e direitos às uniões livres.

Assim, por muito tempo existiu, no Brasil, uma única espécie de família, com características claras e bem definidas: patriarcal, monogâmica, formada pelo casamento e com a finalidade de procriação, visando à transferência do patrimônio. Todas as demais relações não formalizadas pelo casamento não tinham qualquer proteção legal e eram veementemente repudiadas. 
Todavia, com as transformações e os fenômenos sociais que intensificaram no Brasil a partir da metade do século, já não era mais possível à sociedade ignorar as relações afetivas constituídas sem a formalidade do casamento, as quais começaram a se exteriorizar gradativamente. A infelicidade e a inexistência de afeto nas relações familiares não eram mais aceitas passivamente, e as separações e os divórcios tornavam-se fatos sociais aos quais não se permitia mais fechar os olhos. Tudo isso veio a culminar, no ano de 1977, com o advento da Lei do Divórcio.

Da mesma forma, a partir da metade do século $\mathrm{XX}$, os aplicadores do direito, paulatinamente, foram vencendo barreiras e resistências. Assim, a doutrina e a jurisprudência passaram a lapidar gradualmente o conceito atual de união estável e de concubinato, conferido reconhecimento e direitos às uniões informais e estabelecendo distinção entre os dois institutos. Concubina passou a ser considerada exclusivamente aquela mulher que se relacionava com homem casado, na constância do matrimônio, ao passo que companheira era a que mantinha relacionamento com homem desimpedido ou, ao menos, separado de fato.

Diante da possibilidade de se aplicar às relações fáticas as regras relativas à família, visto que, de acordo com o ordenamento jurídico, somente o casamento é que permitia a forma- ção dessa entidade, os tribunais brasileiros passaram a afirmar que duas pessoas vivendo juntas durante certo tempo, com colaboração recíproca na aquisição do patrimônio, formariam uma sociedade de fato, figura que, com o uso da analogia, foi trazida do Direito das Obrigações para regrar essas situações, visando, em última análise, a vedar o enriquecimento ilícito.

A solidificação dessa construção pretoriana acabou por resultar, no ano de 1963, na Súmula 380 do Supremo Tribunal Federal, na qual foi assentado que "comprovada a existência de sociedade de fato entre os concubinos, é cabível sua dissolução judicial, com a partilha do patrimônio adquirido pelo esforço comum”. A redação desse enunciado mostra que o que se reconhecia como hábil para dar direito à partilha dos bens comuns não era apenas o concubinato em si (resultante da convivência mais ou menos duradoura entre homem e mulher), mas, sim, a sociedade de fato, evidenciada pelo esforço comum que se agregava a essa convivência.

Mais proximamente à Constituição Federal de 1988, alguns julgados mais precursores já vinham admitindo a contribuição indireta - a mesma que antes só ensejava indenização por serviços prestados - como suficiente para dar direito à partilha dos bens adquiridos, o que já constituía um prenúncio da admissão das uniões livres como entidades familiares. 
Assim, aos poucos as uniões denominado despatrimonialização do informais deixaram de ser apenas direito privado, no qual o patrimôfatos sociais para se transformarem também em fatos jurídicos.

Todavia, o grande marco de todas essas transformações foi, sem dúvida alguma, o advento da Constituição Federal de $1988^{20}$. A partir de sua promulgação, os princípios da solidariedade, da afetividade, da igualdade e, principalmente, da dignidade da pessoa humana passaram a nortear o Direito de Família, sendo este último eleito pelo legislador constituinte o princípio maior do Estado Democrático de Direito.

O reconhecimento da dignidade da pessoa humana como princípio supremo culmina com o fenômeno nio cede lugar de prioridade à pessoa humana. A constitucionalização do Direito Civil Brasileiro representou a supressão de concepções ultrapassadas, individualistas, tradicionais e elitistas que vigoravam até então.

Coadunando-se com esses novos valores constitucionais inspiradores da sociedade, a entidade familiar passou a ser compreendida sob uma nova ótica. Traçou-se um novo eixo fundamental da família, não apenas consentâneo com a pós-modernidade ${ }^{21}$, mas também afinado com as diretrizes e opções da Carta Constitucional brasileira ${ }^{22}$.

À luz do texto constitucional, a família passou a ser entendida como

20 "[...] a Constituição Federal de 1988 é, sem dúvida nenhuma, uma das maiores conquistas no Direito de Família, porque demonstra, além da importância do contexto familiar para o constituinte, a evolução por que passou” (OLIVEIRA, José Sebastião de. Fundamentos constitucionais do direito de família. São Paulo: Editora Revista dos Tribunais, 2003, p. 223).

21 “A construção do conceito pós-moderno de família representa o conteúdo dos novos paradigmas do Direito de Família, que tem sofrido uma revolução em sua compreensão e sua dinâmica a partir da década de 60 . Identifica-se na família a influenciada ocorrência do revival dos direitos fundamentais, que se concretiza no princípio da dignidade da pessoa humana, sinalizando novos tempos, desenvolvendo-se como conceito jurídico, passando a orientar as constituições dos países ocidentais, a começar pela Alemanha, sede do nazismo. O Brasil logo acompanhou a tendência pós-moderna, ao acolher o axioma do artigo 1º III, da Constituição Federal de 198,8.” (BARBOSA, Águida Arruda. Conceito Pós-moderno de Família. In: HIRONAKA, Giselda Maria Fernandes Novaes (Coord.); TARTUCE, Flávio (Coord.); SIMÃO, José Fernando (Coord). Direito de Família e das Sucessões: temas atuais. São Paulo: Método, 2009, p. 24).

22 CAHALI, Francisco José (Coord.); PEREIRA, Rodrigo da Cunha (Coord.). Alimentos no Código Civil: aspectos civil, constitucional, processual e penal. São Paulo: Saraiva, 2005, p. 22. 
grupo social fundado, essencialmente, por laços de afetividade ${ }^{23}$. E, sendo os laços de afetividade a causa originária e final do núcleo familiar, tornou-se o propósito da família servir de impulsão para a afirmação da dignidade da pessoa de seus componentes.

Inserida nesse novo contexto, a união estável passou a ser reconhecida como uma espécie de entidade familiar, sendo merecedora da tutela estatal. Tal importou, consequentemente, o reconhecimento da família não derivada de casamento civil ou casamento religioso com efeitos civis, e sim formada pela relação extramatrimonial estável entre um homem e uma mulher.

Entretanto, o legislador constitucional não definiu o instituto, cabendo tal tarefa ao legislador ordinário. Como a legislação tardou a chegar, novamente a jurisprudência desempenhou papel relevante para a solução dos conflitos.

Somente em 1994, com a promulgação da Lei n. 8.971, é que a matéria começou a tomar os contornos tal qual é conhecida atualmente. A pri- meira inovação da mencionada lei foi estabelecer o procedimento ao direito de alimentos e sucessão. Com isso, a união extramatrimonial chamada pela Constituição Federal de 1988 como união estável passou definitivamente a surtir efeitos como família, equiparando-se, em alguns aspectos, ao casamento.

Posteriormente, a Lei n. 9.278/96, modificando parcialmente a Lei $\mathrm{n}$. 8.971, de 1994, definiu conceitualmente união estável e estabeleceu um regime de bens básico para essas uniões e, nesse texto, o legislador optou por um regime semelhante ao da comunhão parcial de bens, em que os companheiros criam um patrimônio comum, presumindo-se a colaboração de ambos no decorrer da união.

Finalmente, o Código Civil de 2002 veio a definir e a regular diversas questões envolvendo união estável, tanto no âmbito do Direito de Família como na esfera do Direito das Sucessões.

Todavia, em relação às uniões informais estabelecidas por quem está impedido de casar $^{24}$ (constituindo-

23 FARIAS, Cristiano Chaves de. Escritos de Direito de Família. Rio de Janeiro: Editora Lumen Juris, 2007, p. 13.

24 Art. 1.521. Não podem casar:

I - os ascendentes com os descendentes, seja o parentesco natural ou civil;

II - os afins em linha reta;

III - o adotante com quem foi cônjuge do adotado e o adotado com quem o foi do adotante;

IV - os irmãos, unilaterais ou bilaterais, e demais colaterais, até o terceiro grau inclusive; 
se um desses impedimentos o fato de a pessoa estar casada), o Código Civil limitou-se a defini-las como concubinato $^{25}$, sem a atribuição de qualquer direito patrimonial, nem no Direito de Família, nem no Direito Sucessório, estabelecendo expressamente que tais impedimentos impossibilitam também a constituição de união estável, com a exceção da hipótese de a pessoa casada já estar separada de fato ${ }^{26}$. Ou seja, de acordo com o diploma civilista atual, não pode casar quem está casado, e não pode constituir união estável quem está casado e não separado de fato. Além disso, para a constituição de uma união estável, sacramentou como premissa o objetivo de constituir família e o dever de lealdade, assim como consagrou o dever de fidelidade do cônjuge.

É certo, no entanto, que a realidade social - à qual não se pode fechar os

$\mathrm{V}$ - o adotado com o filho do adotante;

VI - as pessoas casadas;

VII - o cônjuge sobrevivente com o condenado por homicídio ou tentativa de homicídio contra o seu consorte.

[...]

Art. 1.523. Não devem casar:

I - o viúvo ou a viúva que tiver filho do cônjuge falecido, enquanto não fizer inventário dos bens do casal e der partilha aos herdeiros;

II - a viúva, ou a mulher cujo casamento se desfez por ser nulo ou ter sido anulado, até dez meses depois do começo da viuvez, ou da dissolução da sociedade conjugal;

III - o divorciado, enquanto não houver sido homologada ou decidida a partilha dos bens do casal;

IV - o tutor ou o curador e os seus descendentes, ascendentes, irmãos, cunhados ou sobrinhos, com a pessoa tutelada ou curatelada, enquanto não cessar a tutela ou curatela, e não estiverem saldadas as respectivas contas.

Parágrafo único. É permitido aos nubentes solicitar ao juiz que não lhes sejam aplicadas as causas suspensivas previstas nos incisos I, III e IV deste artigo, provando-se a inexistência de prejuízo, respectivamente, para o herdeiro, para o ex-cônjuge e para a pessoa tutelada ou curatelada; no caso do inciso II, a nubente deverá provar nascimento de filho, ou inexistência de gravidez, na fluência do prazo.

25 Art. 1.727. As relações não eventuais entre o homem e a mulher, impedidos de casar, constituem concubinato.

26 Art. 1.723. É reconhecida como entidade familiar a união estável entre o homem e a mulher, configurada na convivência pública, contínua e duradoura e estabelecida com o objetivo de constituição de família.

§ 1o A união estável não se constituirá se ocorrerem os impedimentos do art. 1.521; não se aplicando a incidência do inciso VI no caso de a pessoa casada se achar separada de fato ou judicialmente. 
olhos - nos apresenta uma enorme quantidade de uniões informais paralelas ao casamento ou simultâneas a uma união estável, o que, em uma sociedade pós-moderna marcada por relações frágeis e fragmentadas, tende a aumentar. E, mesmo com a toda evolução histórica e os inegáveis avanços trazidos pela novel legislação civilista brasileira no âmbito do Direito de Família e das Sucessões, inexiste solução jurídica consolidada para os casos de ruptura de tais relações, transformando-se o tema em permanente fonte de indagações e controvérsias.

\subsection{EVOLUÇÃO E NOVAS PERSPECTIVAS DO DIREITO DAS SUCESSÕES}

Assim como o Direito de Família (onde está alicerçada sua base), o Direito das Sucessões ${ }^{27}$ vem sofrendo diversas modificações ao longo de sua história.
Tendo como sua principal finalidade a conservação e o melhoramento da existência, a transmissão do patrimônio para os sucessores remonta à antiguidade, registrando os historiadores seus primeiros indicativos nos direitos egípcio, hindu e babilônico ${ }^{28}$. Na Grécia e na Itália - cujas populações, desde os tempos mais remotos, sempre reconheceram e praticaram a propriedade privada -, a sucessão justificava-se por considerações religiosas $^{29}$, constituindo o culto religioso dos antepassados o centro da vida religiosa ${ }^{30}$. Em Roma, o pater famílias (que era o titular do patrimônio), antes de sua morte, escolhia, por testamento, quem passaria a ser o chefe do grupo familiar, ou seja, o sucessor de seu poder soberano e de seus bens, acreditando-se que a morte de alguém sem sucessor ensejava a extinção do culto doméstico, trazendo infelicidade aos mortos ${ }^{31}$. Assim, o homem morria, mas o culto continuava, sendo os herdeiros homens os sacerdotes desse culto.

27 "O Direito das Sucessões é o conjunto de normas jurídicas que disciplinam a transmissão do patrimônio (ativo e passivo) de uma pessoa que morreu a seus sucessores" (LEITE, Eduardo de Oliveira. Direito das Sucessões. In: TEIXEIRA, Sálvio de Figueiredo (Org.). Direito Civil Aplicado. 2. ed. São Paulo: Revista dos Tribunais, 2012, p. 22). 28 NORONHA, Carlos Silveira (Org.). As Novas Perspectivas do Direito das Sucessões em tempos de modernidade e pós-modernidade. Porto Alegre: Sulina, 2011, p. 9. 29 LEITE, op. cit., p. 23.

30 NORONHA, Carlos Silveira (Org.). As Novas Perspectivas do Direito das Sucessões em tempos de modernidade e pós-modernidade. Porto Alegre: Sulina, 2011, p. 11. 31 DIAS, Maria Berenice. Manual das Sucessões. 2. ed., rev., atual. e ampl.. São Paulo: Editora Revista dos Tribunais, 2011, p. 27. 
Inicialmente, a única forma de sucessão era pela via testamentária, e só depois, já no final da fase imperial romana, com Justiniano, implantouse a sucessão legítima ${ }^{32}$.

É certo que, em todas as sociedades organizadas em bases capitalistas, verifica-se que o direito sucessório surge com o reconhecimento natural da propriedade privada ${ }^{33}$.

Para muitos, a "pedra de toque" do direito sucessório foi o chamado princípio da saisine ${ }^{34}$, que teve seus traços iniciais proclamados pela doutrina germânica e passou a ser efetivamente adotado, em 1804, pelo direito francês ${ }^{35}$. Por meio de tal princípio, os herdeiros investem-se na posse e na propriedade dos bens do falecido imediatamente após a morte deste. $\mathrm{O}$ sistema jurídico brasileiro adotou tal princípio, o qual foi expressamente previsto no art. 1.572 do Código Civil de 1916 e reeditado no art. 1.784 do Código Civil de 2002.

Embora toda a legislação brasileira acerca do Direito das Sucessões, desde o seu princípio, tenha sido im- plementada sob uma realidade social fundada no direito patrimonial, as constantes mudanças nas relações familiares ao longo dos anos vêm exigindo alterações legislativas e novas interpretações das normas por parte da doutrina e da jurisprudência. Diante de uma família remodelada, caracterizada por uma realidade complexa e plural, velhos e ultrapassados preceitos não podem permanecer inertes no âmbito sucessório.

Vale lembrar que, no Código de 1916, assim como ocorrera com o Direito de Família, também as regras atinentes ao Direito Sucessório foram elaboradas para regular uma sociedade cuja realidade já está ultrapassada nos dias de hoje. Assim, inúmeras regras tornaram-se retrógradas e descontextualizadas dos fatos sociais e dos novos princípios que passaram a reger o sistema jurídico brasileiro - especialmente após o advento da Constituição de 1988. Cita-se, como exemplo, a diferenciação entre filhos legítimos e ilegítimos no recebimento da herança ${ }^{36}$ e a inexistência de qual-

32 NORONHA, op. cit., p. 12.

33 MAXIMILIANO, Carlos. Direito das sucessões. 5. ed. Rio de Janeiro: Freitas Bastos S.A., 1964, v. I, p. 21, apud DIAS, op. cit., p. 25.

34 DIAS, Maria Berenice. Manual das Sucessões. 2. ed., rev., atual. e ampl.. São Paulo: Editora Revista dos Tribunais, 2011, p. 28.

35 NORONHA, Carlos Silveira (Org.). As Novas Perspectivas do Direito das Sucessões em tempos de modernidade e pós-modernidade. Porto Alegre: Sulina, 2011, p. 12. 36 Art. 1.605. Para os efeitos da sucessão, aos filhos legítimos se equiparam os legitimados, os naturais reconhecidos e os adotivos.

$\S 1^{\circ}$ Havendo filho legítimo, ou legitimado, só a metade do que a este couber em heran- 
quer direito sucessório ao companheiro sobrevivente.

Nesse contexto, o Código Civil de 2002 trouxe uma série de inovações no âmbito do Direito Sucessório - foram mais de 30 novos dispositivos ${ }^{37}$ -, ampliando a abordagem dos temas pertinentes ante as muitas e profundas mutações ocorridas ${ }^{38}$. Alterou completamente, por exemplo, a estrutura da ordem da vocação hereditária. Trouxe novas concepções para herança entre companheiros ${ }^{39}$. Introduziu o direito de concorrência sucessória e elevou o cônjuge à condição de herdeiro necessário ${ }^{40}$. Inovou, ainda, no que diz respeito à legitimação para suceder das pessoas já concebidas ou ainda não concebidas, à petição de herança, à colação e ao fideicomisso, dentre outras questões pontuais, como a simplificação do ato de testar ${ }^{41}$.

O Direito Sucessório passou a ser disciplinado nos arts. 1.784 a 2.027, estando dividido em quatro títulos: (1) da sucessão em geral; (2) da sucessão

ça terá direito o filho natural reconhecido na constância do casamento (art. 358).

$\S 2^{\circ}$ Ao filho adotivo, se concorrer com legítimos, supervenientes a adoção (art. 368), tocará somente metade da herança cabível a cada um destes.

37 LEITE, Eduardo de Oliveira. Direito das Sucessões. In: TEIXEIRA, Sálvio de Figueiredo (Org.). Direito Civil Aplicado. 2. ed. São Paulo: Revista dos Tribunais, 2012, p. 25.

38 "Em seu Livro V, da parte especial, a nossa vigente codificação civil cujo anteprojeto é de lavra do eminente professor Torquato Costa, da Universidade do Recife, aborda com propriedade e clareza os temas pertinentes ao direito das sucessões, no âmbito do qual vem ocorrendo, no andar dos tempos, muitas e profundas mutações, como se constata no Âmbito da doutrina e da própria lei.” [...] “Dessarte, as mudanças que se encontram abrigadas na ordem sucessória, mais que puras e simples inovações 'per se' desse ramo da civilística moderna e pós-moderna, constituem reflexos de situações fáticas ocorrentes no complexo social e de compartimentos da própria ordem jurídica, aliás, como já alhures nos manifestamos em passado recente, e que também ocorre diante da necessidade de proteger a família e o patrimônio que a ela deve permanecer unido, na expressão de Maseau” (NORONHA, Carlos Silveira (Org.). As Novas Perspectivas do Direito das Sucessões em tempos de modernidade e pós-modernidade. Porto Alegre: Sulina, 2011, p. 13).

39 PEREIRA, Rodrigo da Cunha. Concubinato e união estável. 8. ed., rev. e atual. São Paulo: Saraiva, 2012, p. 139 et seq.

40 DIAS, Maria Berenice. Manual das Sucessões. 2. ed., rev., atual. e ampl.. São Paulo: Editora Revista dos Tribunais, 2011, p. 8.

41 "Houve também sensível simplificação do ato de testar, uma vez que o testamento particular passa a poder ser escrito de próprio punho ou digitado, bastando três testemunhas, ou mesmo sem testemunha alguma, devendo, nesse caso, ser posteriormente confirmado por um juiz." (FIUZA, Ricardo (Coord.). Novo Código Civil Comentado. São Paulo: Saraiva, 2002, p. XXXI). 
legítima; (3) da sucessão testamentária; (4) do inventário e da partilha.

Mas nem mesmo as diversas inovações trazidas pelo Código Civil de 2002 foram suficientes para que a legislação civil brasileira ficasse atualizada com essa nova realidade social e com a revolução produzida pelo avanço tecnológico e a facilidade de comunicação ${ }^{42}$ (uma das característi- cas da sociedade pós-moderna). Apesar dos inegáveis avanços trazidos em matéria de Direito Sucessório ${ }^{43}$, o referido diploma vem sendo muito criticado nessa matéria, questionando-se os fatos de ter repetido alguns conceitos ultrapassados ${ }^{44}$, de ter conferido tratamento diferenciado ao cônjuge e ao companheiro ${ }^{45}$ (criticando-se, em especial, os dispositivos que regulam

42 "Principalmente em sede de direito sucessório, o Código Civil esqueceu de acompanhar a fantástica revolução produzida pelo avanço tecnológico e as inúmeras facilidades trazidas ao mundo da comunicação. O máximo que fez foi permitir a elaboração do testamento por processo mecânico. Nada sobre a possibilidade de ser gravado em vídeo, certamente forma mais segura de garantir a liberdade do testador e assegurar o fiel cumprimento de suas determinações. Mas ainda há necessidade de 'cerrar e coser' o testamento. É isso mesmo, o tabelião costura o testamento, o lacar com cera e apõe o seu sinete!” (DIAS, op. cit., p. 8).

43 “O Código Civil de 2002, no entanto, trouxe algumas inovações de grande importância, especialmente no que se refere à sucessão hereditária, incluindo-se o cônjuge na qualidade de herdeiro necessário, em concorrência com os descendentes e ascendentes, e disciplinando a sucessão na união estável; introduziu regras a respeito da petição de herança, à sucessão de direitos à sucessão hereditária; possibilitou mais concretamente a sucessão de filhos ainda não concebidos de pessoas indicadas e vivas quando da abertura da sucessão, e a sucessão de pessoas jurídicas. Modificou a redação de grande parte dos dispositivos que vinha do Código de 1916, melhorando, atualizando e simplificando os textos, embora mantendo a substância dos conteúdos" (RIZZARDO, Arnaldo. Direito das Sucessões: Lei n. 10.406, de 10.01.2022. 5. ed. Rio de Janeiro: Forense, 2009. Prólogo).

44 “Não só de falta de imaginação se ressente o livro do direito das sucessões. Perdeu o legislador uma bela oportunidade de atualizar a maioria dos seus institutos.” [...] “ De restou copiou - e mal - o Código anterior, que era do início do século passado. Servia para regular a sociedade daquela época, mas que não mais se encaixa no modelo social dos dias de hoje". "Na medida em que a sociedade vai evoluindo, a lei precisa acompanhar as mudanças. Infelizmente não foi o que ocorreu com o Código Civil atual, que, em sede de direito sucessório, praticamente copiou o Código anterior. O legislador não teve sequer o cuidado de atualizar sua linguagem. Assim, continua a falar em caducidade quando trata da eficácia das disposições testamentárias" (DIAS, Maria Berenice. Manual das Sucessões. 2. ed., rev., atual. e ampl. São Paulo: Editora Revista dos Tribunais, 2011, p. 8 e 29).

45 VELOSO, Zeno. Direito hereditário do cônjuge e do companheiro. São Paulo: Saraiva, 2010, p. 15. 
os direitos sucessórios deste último ${ }^{46}$ ), e de ter se furtado de conferir tratamento jurídico a algumas espécies de relações cuja existência não se pode negar ${ }^{47}$.

Assim como ocorrera no Direito de Família, o Código Civil de 2002 não contemplou qualquer tratamento jurídico às relações paralelas no âmbito do Direito das Sucessões, limitando-se apenas a restringir os direitos oriundos de relações concubinárias.

Todavia, com o falecimento de um dos envolvidos nas relações paralelas, são inúmeras as indagações que surgem acerca dos efeitos patrimoniais delas decorrentes. Discutem-se, no âmbito do Direito Sucessório, questões de extrema relevância, tais como se deve ser considerada a meação do concubino do patrimônio do falecido eventual (o que interfere fundamentalmente na apuração do monte-mor partilhável); se o concubino tem direito à herança, e como se dá tal participação em relação aos filhos e ao cônjuge ou companheiro supérstite; se o concubino faz jus à pensão por morte, ao seguro de vida e ao direito real de habitação; e, ainda, se é possível ser flexibilizada a regra que impede o legado e a doação testamentária ao concubino.

De um lado, há impedimentos de ordem legal, moral e religiosa para a concessão de efeitos patrimoniais (que não estão previstos no ordenamento jurídico) no caso de falecimento de um dos integrantes da relação paralela. De outro, não se pode olvidar que, assim como no Direito de Família, um dos fundamentos do Direito Sucessório é o afeto, sendo impositivo invocar, também em matéria de sucessões, o princípio fundamental da dignidade da pessoa humana ${ }^{48}$.

46 "No tema que me foi proposto para este Congresso - Direito Sucessório e Constituição: controvérsias e tendências -, estes cuidados para com a realização de tão grande poder não foram bem observados pelo legislador do Código Civil de 2002, infelizmente, o que tem trazido, nestes mais de cinco anos de vigência da Lei Civil, grande insegurança e, quiçá, impressões de injustiça nos julgados que por todo o país se repetem. Trazendo soluções diferentes para situações fáticas iguais. Refiro-me, aqui, expressamente - e num recorte de conteúdo que devo fazer dentro do grande tema -, a um dos mais aflitivos momentos legislativos do Código Civil brasileiro, qual seja, a (in)constitucionalidade do art. 1.790 do Código Civil brasileiro, dispositivo este que cuida do direito sucessório das pessoas que vivem em união estável” (HIRONAKA, Giselda Maria Fernandes Novaes. Direito Sucessório e Constituição: Controvérsias e Tendências. In: HIRONAKA, Giselda Maria Fernandes Novaes (Coord.); TARTUCE, Flávio (Coord.); SIMÃO, José Fernando (Coord). Direito de Família e das Sucessões: temas atuais. São Paulo: Método, 2009, p. 455).

47 Como, por exemplo, relações homoafetivas.

48 DIAS, op. cit., p. 32. 


\section{UNIÕES PARALELAS E SEUS EFEITOS NO DIREITO DAS SUCESSÕES}

O tema envolvendo as uniões paralelas ainda é objeto de amplo e acirrado debate jurídico, havendo distintos posicionamentos doutrinários e jurisprudências acerca de seu reconhecimento jurídico e, especialmente, dos efeitos patrimoniais que geram no Direito de Família e no Direito das Sucessões.

\subsection{Uniões paralelas e a polêmica acerca de seu reconhecimento jurídico}

Há pelo menos duas modalidades de uniões informais paralelas que pos- suem alguma relevância para o mundo jurídico (seja no Direito de Família e das Sucessões, seja em outros ramos do Direito, como o das Obrigações). A primeira é a união informal paralela a um casamento preexistente. A segunda é a união informal paralela ou simultânea a uma união estável.

Como visto, a legislação brasileira não atribui qualquer espécie de efeito patrimonial a essas modalidades de relações, nem no Direito de Família, nem no Direito das Sucessões, uma vez que todas as normas existentes acerca do concubinato no Código Civil - artigos $550^{49}, 1.642^{50}, 1.708^{51}$, $1.272^{52}, 1.801^{53}$ e $1.803^{54}$ - são restritivas de direitos. Assim, diante do silêncio do legislador em atribuir ou

49 Art. 550. A doação do cônjuge adúltero ao seu cúmplice pode ser anulada pelo outro cônjuge, ou por seus herdeiros necessários, até dois anos depois de dissolvida a sociedade conjugal.

50 Art. 1.642. Qualquer que seja o regime de bens, tanto o marido quanto a mulher podem livremente:

[...]

V - reivindicar os bens comuns, móveis ou imóveis, doados ou transferidos pelo outro cônjuge ao concubino, desde que provado que os bens não foram adquiridos pelo esforço comum destes, se o casal estiver separado de fato por mais de cinco anos.

51 Art. 1.708. Com o casamento, a união estável ou o concubinato do credor, cessa o dever de prestar alimentos.

52 Art. 1.727. As relações não eventuais entre o homem e a mulher, impedidos de casar, constituem concubinato.

53 Art. 1.801. Não podem ser nomeados herdeiros nem legatários:

[...]

III - o concubino do testador casado, salvo se este, sem culpa sua, estiver separado de fato do cônjuge há mais de cinco anos.

54 Art. 1.803. É lícita a deixa ao filho do concubino, quando também o for do testador. 
negar expressamente efeitos patrimoniais ao concubinato, e da necessidade de análise pelo Judiciário de questões fáticas decorrentes dessa modalidade de relacionamento reincidente na sociedade (trata-se de uma realidade social), a doutrina e a jurisprudência (assim como esta última já o fizera em relação ao concubinato puro, antes do reconhecimento legal da união estável, citando-se, como exemplo, as Súmulas $35^{55}, 380^{56}, 382^{57}, 447^{58}$, todas datadas do ano de 1964) vêm cuidando de enfrentar a problemática, ainda se encontrando na busca do melhor tratamento jurídico a ser conferido a tais relações.

Quanto ao enquadramento jurídico das relações paralelas e seus efei- tos jurídicos na esfera patrimonial, há distintos critérios que são utilizados para definir as correntes doutrinárias e jurisprudências existentes. Utiliza-se, no presente trabalho, para uma melhor compreensão, classificação que aponta dois grandes posicionamentos acerca do tema, apontando-se, dentre eles, respectivas subdivisões. Entende-se, assim, que o posicionamento jurisprudencial, em especial, será retratado com maior fidedignidade ${ }^{59}$.

$\mathrm{O}$ primeiro posicionamento entende, como regra, que as uniões paralelas não podem ser reconhecidas como entidade familiar equiparável à união estável (nesse sentido Zeno Ve$\operatorname{loso}^{60}$, Rolf Madaleno ${ }^{61}$, Euclides de

55 Súmula 35: EM CASO DE ACIDENTE DO TRABALHO OU DE TRANSPORTE, A CONCUBINA TEM DIREITO DE SER INDENIZADA PELA MORTE DO AMÁSIO, SE ENTRE ELES NÃO HAVIA IMPEDIMENTO PARA O MATRIMÔNIO.

56 Súmula 380: COMPROVADA A EXISTÊNCIA DE SOCIEDADE DE FATO ENTRE OS CONCUBINOS, É CABÍVEL A SUA DISSOLUÇÃO JUDICIAL, COM A PARTILHA DO PATRIMÔNIO ADQUIRIDO PELO ESFORÇO COMUM.

57 Súmula 382: A VIDA EM COMUM SOB O MESMO TETO, "MORE UXORIO”, NÃO É INDISPENSÁVEL À CARACTERIZAÇÃO DO CONCUBINATO.

58 Súmula 447: É VÁLIDA A DISPOSIÇÃO TESTAMENTÁRIA EM FAVOR DE FILHO ADULTERINO DO TESTADOR COM SUA CONCUBINA.

59 Isso porque a maioria dos julgados entende que as uniões paralelas não podem constituir união estável. Muitas dessas decisões, todavia, não excluem a possibilidade de reconhecimento de união estável putativa, já que os casos em exame não exigiram tal análise. 60 "Fora desse caso [união estável putativa], que, sem dúvida, é excepcional, o concubinato não gera efeitos na órbita familiar e sucessória. O concubino não é herdeiro, considerando as regras da sucessão legítima, nem pode ser nomeado herdeiro nem legatário pelo outro concubino se este for casado e estiver convivendo com o cônjuge" (VELOSO, Zeno. Direito hereditário do cônjuge e do companheiro. São Paulo: Saraiva, 2010, p. 207).

61 "A relação adulterina configura sem sombra de dúvida um fato social, capaz até de gerar resultados jurídicos no plano do Direito das Obrigações, mas jamais poderá 
Oliveira $^{62}$, Renata Almeida e Walsir Edson Rodrigues Júnior ${ }^{63}$ ), entendendo que devem ser tratadas como um instituto pertencente ao direito das obrigações, ou seja, fora do campo do Direito de Família. Isso porque não haveria como uma relação dessa natureza preencher os requisitos exigidos pelo legislador para a constituição de uma união estável - em especial o requisito da lealdade -, além de ferir o princípio da monogamia ${ }^{64}$.
Nesse caso, a relação paralela configuraria mera sociedade de fato, devendo haver prova de contribuição efetiva e direta na constituição do patrimônio para que haja partilha de bens, exatamente como previsto na Súmula 380 do STF. Há casos, ainda, em que, diante da impossibilidade de comprovação de contribuição direta na formação do patrimônio, concede-se ao concubino indenização pelos serviços prestados (como menciona-

alcançar a categoria de fato jurídico do Direito de Família, no modelo puro de uma entidade familiar" (MADALENO, Rolf. Curso de direito de família. 4. ed., rev., atual. e ampl. Rio de Janeiro: Forense, 2011, p. 1.090).

62 "A definição dada ao concubinato parece evidenciar o intuito do legislador em extremar esse regime de convivência daquele outro, cuidado no artigo 1.723, que se aplica à união estável, com os correspondentes direitos exclusivos desta forma de relacionamento familiar. Dizendo melhor, a união dita concubinária não é subespécie de união estável. Constitui, isto sim, uma figura jurídica própria, com contorno diverso do que se acha prescrito na lei para a constituição de uma entidade familiar" (OLIVEIRA, Euclides. União Estável na Jurisprudência do STJ e do STF. In: HIRONAKA, Giselda Maria Fernandes Novaes (Coord.); TARTUCE, Flávio (Coord.); SIMÃO, José Fernando (Coord). Direito de Família e das Sucessões: temas atuais. São Paulo: Método, 2009, p. 218).

63 "Em suma, cumpridos os pressupostos familiares próprios - afetividade, estabilidade e ostentabilidade - a transparência do segundo núcleo convivencial formado serve para satisfazer a lealdade, porque permite ao membro do primeiro avaliar se elegeu, ou não, para si, a monogamia como parâmetro comportamental. Se elegeu, fatalmente desfará o vínculo familiar em face da ofensa. Mas se assim não fizer, isso talvez signifique que a exclusividade conjugal ou de companheirismo não os vincule. O Direito, nesse último caso, não pode negar reconhecimento e concessão de efeitos jurídicos a ambas as entidades familiares" (ALMEIDA, Renata Barbosa de; RODRIGUES JÚNIOR, Walsir Edson. Direito Civil: Famílias. Rio de Janeiro: Lumen Juris, 2010).

64 “APELAÇÃO CÍVEL. ALEGAÇÃO DE EXISTÊNCIA DE UNIÃO ESTÁVEL. RELACIONAMENTO PARALELO AO CASAMENTO DO FALECIDO. Não se pode reconhecer união estável simultaneamente à hígida existência de casamento, se não restar cabalmente provada a alegada separação de fato. Só assim estará afastado o impedimento legal à constituição de união estável previsto no §1o do art. 1.723. Isso porque o Direito pátrio consagra o princípio da monogamia e não tolera a concomitância de entidades familiares. Igualmente, não há falar em união estável putativa, pois ausente a boa-fé da recorrente, que conhecia a situação conjugal do de cujus. NEGARAM 
do por José Carlos Teixeira Giorgis ${ }^{65}$ ). Com efeito, os direitos concedidos aos concubinos nessas hipóteses o são para evitar uma situação de enriquecimento ilícito.

O enquadramento das relações paralelas como sociedades de fato é o posicionamento predominante no Tribunal de Justiça do Rio Grande do Sul $^{66}$ e já se encontra pacificado no
Superior Tribunal de Justiça, como destacado no seu mais recente julgado acerca da matéria, de relatoria do ministro Luis Felipe Salomão ${ }^{67}$. Anteriormente a tal decisão, também já se pronunciaram sobre a matéria os ministros Fernando Gonçalves ${ }^{68}$, Jorge Scartezinni ${ }^{69}$, Luis Felipe Salomão ${ }^{70}$, Massami Uyeda ${ }^{71}$, Nancy Andrighi ${ }^{72}$, Jorge Mussi ${ }^{73}$, Laurita $\mathrm{Vaz}^{74}$, Marco

PROVIMENTO, À UNANIMIDADE” (Tribunal de Justiça do RS, Apelação Cível n. 70010479046, Sétima Câmara Cível, Relator Luiz Felipe Brasil Santos, julgado em 13/04/2005).

65 “Agora sem acesso aos alimentos ou patrimônio, salvante a relação putativa, é justo que os julgadores reexaminem, como no passado, a possibilidade de o concubino usufruir indenização pela vida em comum, porque não havido acervo durante a convivência ou prova da contribuição na sociedade de fato, é aceitável se cogitar de uma indenização por serviços domésticos, consoante a antiga elaboração jurisprudencial que precisa ressurgir [...] O valor da indenização, afastado por aviltante o cálculo com base no salário-mínimo por ano de convívio, deve considerar as condições econômicas dos envolvidos e a situação fática do caso concreto. Reitere-se, é a solução que mais se abebera do cálice sagrado do respeito à dignidade da pessoa humana” (GIORGIS, José Carlos Teixeira. Direito de família contemporâneo. Porto Alegre: Livraria do Advogado Editora, 2010, p. 127-128).

66 Vide acórdãos de n. 70045787967, 70047104138, 70041309352, 70048240527, 70040703118, 70031056070, 70039843412, 70023332794, 70017086919, 70016434003 (Des. Sérgio Fernando de Vasconcellos Chaves), 70045138054 (Des. Jorge Luís Dall’Agnol), 70044142065 (Des. Roberto Carvalho Fraga), 70047479183, 70048164511, 70048053490, 70047477062, 70046236667 (Des. Ricardo Moreira Lins Pastl), 70042009399, 70042574426,70038714812 , 70046652137 (Des. Luiz Felipe Brasil Santos), 70044949378 e 70036562569 (Des. Alzir Felippe Schmitz).

67 Vide REsp 1096539/RS, julgado em 27/03/2012.

68 Vide REsp 229.069/SP, julgado em 26/4/2005.

69 Vide REsp 684.407/RS, julgado em 03/05/2005.

70 Vide REsp 912.926/RS, julgado em 22/02/2011.

71 Vide REsp 1107192/PR, julgado em 20/04/2010.

72 Vide REsp 1157273/RN, julgado em 18/05/2010.

73 Vide AgRg no REsp 1267832/RS, julgado em 13/12/2011.

74 Vide RMS 30.414/PB, julgado em 17/04/2012. 
Buzzi $^{75}$, Maria Thereza de Assis Moura $^{76}$, e dos Desembargadores convocados Vasco Della Gisutina ${ }^{77}$ e Adilson Vieira Macabu ${ }^{78}$.

Parte dos que defendem esse primeiro posicionamento entende que em hipótese alguma as uniões paralelas poderiam ser equiparadas a uma união estável, independentemente do fato de terem sido constituídas de boa-fé ou de má-fé. Assim, não poderia ser admitida nem mesmo a constituição de uma união estável putativa. Nesse sentido, cita-se julgado do Superior Tribunal de Justiça do ano de 2006, de relatoria do ministro Carlos Alberto Menezes Direito, cujo voto ${ }^{79}$ é esclarecedor quanto à posição adotada.

Grande parte dos que defendem o primeiro posicionamento, todavia, ressalva que, nos casos em que a união paralela é constituída de boa-fé, ou seja, em que um integrante da relação desconhece o impedimento do outro para casar ou constituir união estável, é possível que a relação paralela seja reconhecida como uma união estável putativa, gerando os mesmos efeitos de uma união estável propriamente dita $^{80}$. Esse é o entendimento de Zeno

75 Vide AgRg no REsp 968.572/RN, julgado em 07/02/2012.

76 Vide REsp 1104316/RS, julgado em 28/04/2009.

77 Vide AgRg no Ag 1130816/MG, julgado em 19/08/2010.

78 Vide AgRg nos EDcl no REsp 1059029/RS, julgado em 15/02/2011.

79 Trecho do Voto do ministro Relator Carlos Alberto Menezes Direito: “O objetivo do reconhecimento da união estável e o reconhecimento de que essa união é entidade familiar, na minha concepção, não autoriza que se identifiquem várias uniões estáveis sob a capa de que haveria também uma união estável putativa. Seria, na verdade, reconhecer o impossível, ou seja, a existência de várias convivências com o objetivo de constituir família. Isso levaria, necessariamente, à possibilidade absurda de se reconhecer entidades familiares múltiplas e concomitantes". [...] "Essa circunstância, na minha compreensão, tira qualquer possibilidade do emprego analógico da regra do casamento putativo, porque, enquanto neste existe o vínculo formal duplo, o que é possível, naquele só existe a convivência com aquela vocação de constituir família, havendo, portanto, um vínculo não formal. Ora, se o falecido José Neres de Souza não se desvinculou da convivência mantida com a recorrente, a união estável estava caracterizada aqui, sendo a apelada, então, um relacionamento amoroso que não se pode identificar com união estável, muito menos equipará-lo com o casamento putativo".

80 UNIÃO ESTÁVEL. SITUAÇÃO PUTATIVA. AFFECTIO MARITALIS. NOTORIEDADE E PUBLICIDADE DO RELACIONAMENTO. BOA-FÉ DA COMPANHEIRA. PROVA DOCUMENTAL E TESTEMUNHAL. JUNTADA DE DOCUMENTOS COM A APELAÇÃO. DESCABIMENTO. [...] 3. Comprovada a notoriedade e a publicidade do relacionamento amoroso havido entre a autora e o de cujus, é cabível o reconhecimento de união estável putativa, quando fica demonstrado que a autora não sabia do 


\section{Veloso $^{81}$, Rolf Madaleno ${ }^{82}$, Álvaro e Rodrigo da Cunha Pereira ${ }^{85}$ (embora Villaça $^{83}$, e Eduardo de Oliveira Leite ${ }^{84}$ este último já venha cogitando a}

relacionamento paralelo do varão com a mãe da ré. Recurso provido. (SEGREDO DE JUSTIÇA) (Tribunal de Justiça do RS, Apelação Cível n. 70025094707, Sétima Câmara Cível, Relator Sérgio Fernando de Vasconcellos Chaves, Julgado em 22/10/2008).

81 É possível ocorrer, entretanto, que uma pessoa se encontre envolvida numa relação de concubinato, objetivamente falando, mas esteja de boa-fé, não sabendo, por exemplo, que o parceiro é casado e convive também com o cônjuge. [...] Nessa hipótese, tudo o que se destina aos companheiros - inclusive direito hereditário - pode ser requerido pelo que ostenta a qualidade de companheiro putativo, aplicando-se o art. 1.790 do CC” (VELOSO, Zeno. Direito hereditário do cônjuge e do companheiro. São Paulo: Saraiva, 2010, p. 207).

82 "Desconhecendo a deslealdade do parceiro casado, instaura-se uma nítida situação de união estável putativa, devendo ser reconhecidos os direitos do companheiro inocente, o qual ignorava o estado civil de seu parceiro afetivo, e tampouco a existência fática e jurídica do precedente matrimônio, fazendo jus, salvo contrário escrito, à meação dos bens amealhados onerosamente na constância da união estável putativa em nome do parceiro infiel, sem prejuízo de outras reivindicações jurídicas, como uma pensão alimentícia, se provar a dependência financeira do companheiro casado, e, se porventura o seu parceiro vier a falecer na constância da união estável putativa, poderá se habilitar à herança do de cujus, em relação aos bens comuns, se concorrer com filhos próprios ou a toda herança se concorrer com outros parentes” (MADALENO, Rolf. Curso de direito de família. 4. ed., rev., atual. e ampl. Rio de Janeiro: Forense, 2011, p. 1.094).

83 “[...] concubinato impuro ou concubinagem, não deve merecer apoio dos órgãos públicos e, mesmo, da sociedade. Entendemos, ainda, que deste não deve surtir efeito, a não ser o concubinato de boa-fé, como acontece, analogamente, com o casamento putativo, e para evitar-se locupletamento ilícito” (AZEVEDO, Álvaro Villaça. Estatuto da Família de Fato. São Paulo: Jurídica Brasileira, 2001, p. 311).

84 “Assim como não é possível o casamento para pessoas já casadas, enquanto não dissolvido o vínculo conjugal, também não se admite, pelo rigor legislativo do princípio monogâmico, a constituição de família mediante união estável paralela, quando subsista impedimento matrimonial (art. 1.723,§ $1^{\circ}$, do CC). A conclusão se reforça com a norma do art. 1.723 do mesmo Código, definindo a situação do concubinato exatamente nas situações em que haja impedimentos. Caberia exceção apenas no caso de uma segunda união de boa-fé, putativa, como previsto para o casamento nulo ou anulável, a produzir efeitos até o dia da sentença anulatória (art. 1.561 do CC). Essa é uma hipótese rara, em vista do requisito da publicidade da união estável, que levaria ao conhecimento social da convivência paralela" (OLIVEIRA, Euclides. União Estável na Jurisprudência do STJ e do STF. In: HIRONAKA, Giselda Maria Fernandes Novaes (Coord.); TARTUCE, Flávio (Coord.); SIMÃO, José Fernando (Coord). Direito de Família e das Sucessões: temas atuais. São Paulo: Método, 2009, p. 222).

85 "Um dos princípios basilares da organização jurídica sobre a família é o da monogamia. Por isso, o ordenamento jurídico não prevê a constituição de duas uniões estáveis simultaneamente, assim como é impossível dois casamentos simultâneos. Situação diversa, entretanto, é aquela em que a pessoa que mantém duas relações, oculta 
possibilidade de reconhecer amplos efeitos jurídicos ao concubinato ${ }^{86}$ ).

Merece registro a dificuldade de prova acerca da boa-fé ou má-fé do concubino. Aliás, trata-se de prova praticamente impossível (prova negativa) a de que não se sabia do casamento ou a união estável já constituída pelo outro integrante da relação. Quanto à complexidade dessa prova, Maria Berenice Dias assevera que "perquirir a boa ou a má-fé é tarefa complexa, além de haver o perigo de se cair no puro subjetivismo" ${ }^{87}$.

Sem falar que tal questão enseja uma série de outras discussões. É possível que por muitos anos um dos integrantes da relação paralela não tenha conhecimento de que o parceiro é casado ou possui união estável, mas depois vem a descobrir, continuando com a relação. Nesse caso, estar-se-ia, ao mesmo tempo, diante de uma relação de boa-fé e de má-fé. Sem contar, ainda, a possibilidade de que todos os envolvidos na relação estejam de má-fé, inclusive a esposa ou companheira.

Já a segunda corrente sustenta que não há qualquer óbice para que as relações paralelas (sejam elas de má-fé ou de boa-fé) sejam reconhecidas como união estável. Estando ambas

essa realidade de seu parceiro(a). Se porventura subsistir a caracterização simultânea de duas ou mais uniões, socorre à parte que ignorava a situação o instituto da União Estável putativa, ou seja, aquele em que um dos partícipes desconhecia por completo a existência de outra união more uxorio - matrimonial ou extramatrimonial - do outro, devendo esta produzir os mesmos efeitos previstos, para uma união monogâmica” (PEREIRA, Rodrigo da Cunha. Concubinato e união estável. 8. ed., rev. e atual. São Paulo: Saraiva, 2012, p. 100).

86 "Mas se o fato de ferir este princípio significar fazer injustiça, devemos recorrer ao valor maior, que é o da prevalência da ética sobre a moral, para que possamos aproximar do ideal de justiça (ver Capítulo 3 - Moral e Ética - uma distinção necessária para aplicação dos princípios). Ademais, se considerarmos a interferência da subjetividade dos atos e fatos jurídicos, concluiremos que o imperativo ético passa a ser a consideração do sujeito na relação e não mais o objeto da relação. Isto significa colocar em prática o que disse antes, ou seja, que o Direito deve proteger a essência e não a forma, ainda que isto custe 'arranhar' o princípio jurídico da monogamia. Se o fim dos princípios jurídicos é ajudar a atingir um bem maior, ou seja, a justiça, este paradoxo do concubinato adulterino deve ser resolvido, então, em cada julgamento, e cada julgador aplicando outros princípios e a subjetividade que cada caso pode conter é quem deverá aplicar a justiça, dentro de seu poder de discricionariedade. Assim, estaremos preservando o princípio jurídico da monogamia, eixo gravitacional sob o qual todo o Direito de Família está estruturado" (Idem. Princípios fundamentais norteadores do direito de família. Belo Horizonte: Del Rey, 2006, p. 145).

87 DIAS, Maria Berenice. Manual de Direito das Famílias. 7. ed., rev., atual. e ampl. São Paulo: Editora Revista dos Tribunais, 2010, p. 51. 
as relações fundadas no afeto, devem ser equiparadas, gerando os mesmos efeitos. Nesse sentido, o posicionamento de Maria Berenice Dias, para quem “presentes os requisitos legais, é mister que a justiça reconheça que tais vínculos afetivos configuram união estável, sob pena de dar uma resposta que afronta a ética, chancelando o enriquecimento injustificado"88. Para ela, "o companheirismo, seja classificado como de boa ou má-fé, deve ser considerado entidade familiar. [...] Negar a existência de famílias paralelas - quer um casamento e uma união estável, quer duas ou mais uniões estáveis - é simplesmente não ver a realidade" ${ }^{\text {" }}$. Aliás, segundo a referida autora, é justamente a ausência de concessão de efeitos jurídicos a tais relações uma das causas de sua proliferação $0^{90}$.

Também comungam desse entendimento Renata Barbosa de Almeida, Walsir Edson Rodrigues Júnior ${ }^{91}$ e Anderson Schreiber ${ }^{92}$, segundo os quais a monogamia não é um princí-

88 DIAS, Maria Berenice. Manual de Direito das Famílias. 7. ed., rev., atual. e ampl. São Paulo: Editora Revista dos Tribunais, 2010, p. 50.

89 Ibidem, p. 51.

90 "É de tal ordem a tentativa de condenar a mulher que, apesar de ser o homem que descumpre o preceito monogâmico, a lei sequer se preocupa em evitar o enriquecimento sem causa. Ao não atribuir consequência jurídica a estas estruturas - que ninguém duvida que existam -, obtém efeito inverso? Acaba incentivando uniões paralelas. Aliás, é por isso que não deixam de existir e em larga escala. A repulsa legal aos vínculos afetivos concomitantes não os faz desaparecer; ao contrário. Estimula que se proliferem. Aquele que faz parte de uma célula precisa assumir obrigações, mas quem mantém família concomitantes acaba livre de quaisquer encargos (Idem. Manual das Sucessões. 2. ed., rev., atual. e ampl.. São Paulo: Editora Revista dos Tribunais, 2011, p. 89).

91 "Por essas principais razões, soa temerário interpretar o artigo 1.727 do Código Civil de 2002 como norma excludente e discriminatória. A situação nela indicada pode corresponder sim a uma entidade familiar, desde que se possam verificar, em concreto, os respectivos pressupostos. A própria redação normativa permite esse pensamento: ela não veda a qualidade familiar do que nomina de concubinato. E, não a vedando, também não impede seu reconhecimento. [...] Dados todos esses aspectos, conclui-se: suplantada a necessidade de que os companheiros possam se casar para então ser possível configurar união estável. Suplantada também a monogamia como princípio jurídico, pode-se entender que também é união estável a conjugalidade familiar simultânea ao matrimônio" (ALMEIDA, Renata Barbosa de; RODRIGUES JÚNIOR, Walsir Edson. Direito Civil: Famílias. Rio de Janeiro: Lumen Juris, 2010, p. 316).

92 "Tal atentado à Constituição revela-se ainda mais grave quando se observa que a simultaneidade familiar é fenômeno de frequência significativa na realidade brasileira, sendo certo que negar efeitos jurídicos a uma realidade tão evidente contra toda a evolução mais recente do direito de família, marcada pelo reconhecimento de juridicidade 
pio jurídico. Ainda nesse sentido, Silvio Sálvio Venosa sustenta que os direitos atinentes à união estável podem ser aplicados ao concubinato ${ }^{93}$.

No Tribunal de Justiça do Rio Grande do Sul, podem ser encontrados julgados que entendem possível a constituição de união estável paralela a um casamento ou simultânea a uma união estáve $\mathrm{l}^{94}$.

Da análise dos posicionamentos acima, depreende-se que o ponto decisivo para eleger uma ou outra solução jurídica como a mais apropriada a ser aplicada às relações paralelas passa, necessariamente, pela admissão ou não da monogamia como um princípio jurídico vigente.
Para aqueles que entendem que a monogamia não é um princípio, inexiste óbice para o reconhecimento das uniões paralelas como verdadeiras entidades familiares, devendo ser atribuídas a elas os mesmos efeitos decorrentes da união estável (desde que, é claro, presentes os demais requisitos caraterizadores de tal espécie de união).

Já para aqueles que consideram a monogamia um princípio, e que o mesmo ainda está vigente no sistema jurídico brasileiro, não há como considerar uma relação paralela entidade familiar, muito menos equiparável à união estável, sendo admitido, por alguns, a possibilidade de relativização de tal princípio apenas na hipótese de

a relações de convivência desenvolvidas na prática social. É o que se vê, com particular clareza, no exame das uniões estáveis, cuja disciplina em nada se opõe à sua ocorrência simultânea” (SCHREIBER, Anderson. Família Simultâneas e Redes Familiares. In: HIRONAKA, Giselda Maria Fernandes Novaes (Coord.); TARTUCE, Flávio (Coord.); SIMÃO, José Fernando (Coord). Direito de Família e das Sucessões: temas atuais. São Paulo: Método, 2009, p. 241).

93 "O art. 1.727, já citado, define como concubinato as relações não eventuais entre o homem e a mulher impedidos de casar. Tal, por si só, não retira dessa modalidade de união todo o rol de direitos atribuídos à união estável, assim definida em lei. Não é essa a conclusão a que se há que chegar. Impõe-se verificar em cada caso, ainda que a situação seja de concubinato na concepção legal, quais os direitos de união estável que podem ser atribuídos aos concubinos [...]" (VENOSA, Sílvio de Salvo. Direito de família. In: Direito civil. 6. ed. São Paulo: Atlas, 2006, v. 6, p. 51).

94 De relatoria dos atuais Desembargadores Rui Portanova (vide acórdãos n.. 70022775605, 70024804015, 70009786419, 70011258605, 70006936900, 70027512763) e Alzir Felippe Schmitz (acórdão n. 70024428104). Além de julgados dos ex-Desembargadores Maria Berenice Dias (vide acórdãos n. 70010787398) e Alfredo Guilherme Englert (vide acórdão n. 70011258605), José Ataídes Siqueira Trindade (vide acórdão n. 70012696068). 
desconhecimento de que o mesmo estava sendo ferido (boa-fé).

\subsection{Efeitos jurídicos no direito sucessório}

Em que pese, como já demonstrado, o Código Civil de 2002 não prever qualquer direito decorrente do falecimento de um dos integrantes de uma relação paralela ao outro integrante, diversas são as questões que surgem diante de tal situação. E tais questionamentos vêm sendo submetidos ao Judiciário com uma frequência cada vez maior (o que se atribui não só às novas concepções do Direito de Família e das Sucessões, mas também ao aumento da ocorrência de tais relações, uma das consequências da fragilidade das relações e da fragmentação dos sentimentos característicos da pós-modernidade).

Sem o objetivo de esgotar as postulações judiciais que podem ser originadas com a morte de um dos integrantes de uma relação paralela, passa-se a analisar as principais questões que vêm sendo submetidas à apreciação do Judiciário.

A primeira discussão que se abre acerca das relações paralelas no âmbito do Direito Sucessório envolve a possibilidade de participação do integrante sobrevivente da relação na herança deixada pelo falecido.

Seguindo a posição adotada pelo Código Civil de 2002, e o entendimento predominante de que a relação paralela não constitui união estável, mas, sim, sociedade de fato, exigindo prova da contribuição direta para que haja partilha de bens, o posicionamento majoritário da jurisprudência é no sentido de que o participante sobrevivente da relação não participa da herança, salvo se comprovar contribuição direita na constituição do patrimônio ${ }^{95}$.

Em contrapartida, há um posicionamento minoritário no sentido de

95 "DIREITO PROCESSUAL CIVIL E DIREITO CIVIL. FAMÍLIA. RECURSO ESPECIAL. AÇÃO DE RECONHECIMENTO DE SOCIEDADE DE FATO POST MORTEM. PRELIMINARES DE AUSÊNCIA DE OMISSÃO, CONTRADIÇÃO, OBSCURIDADE, PREQUESTIONAMENTO E SIMILITUDE FÁTICA. REGRAS LOCAIS DE DISTRIBUIÇÃO DE COMPETÊNCIA. NÃO OCORRÊNCIA DE JULGAMENTO ALÉM DO PEDIDO. AUSÊNCIA DE COMPROVAÇÃO DO ESFORÇO COMUM NA AQUISIÇÃO DE EVENTUAL PATRIMÔNIO A SER PARTILHADO. REQUISITO PARA FINS DE RECONHECIMENTO DA SOCIEDADE DE FATO. 1. Consiste a lide em definir se a comprovação do esforço comum na aquisição de eventual patrimônio a ser partilhado - ainda que a partilha seja postulada em lide diversa constitui requisito para fins de reconhecimento de sociedade de fato. 2. Descabe ao STJ imiscuir-se na interpretação de lei local que se exaure na esfera de competência do Tribunal estadual a que está vinculada. [...] 6. A realidade vívida e visceral de uma socie- 
que os concubinos têm os mesmos direitos sucessórios atribuídos aos companheiros na união estável, pois devem ser reconhecidos os mesmos direitos desta às uniões paralelas. Nesse sentido, sustenta Maria Berenice Dias ${ }^{96}$ que, na hipótese de manter o varão duas uniões estáveis concomitantes, o acervo sucessório deve ser partilhado entre os companheiros sobreviventes. E, no caso de união estável paralela ao casamento, deve-se primeiro se afastar a meação da viúva (dependendo do regime de bens); após, excluir-se a legítima dos herdeiros e, por fim, a parte disponível dos bens adquiridos durante o período da união ser divida com a companheira, sendo dispensada a prova do esforço comum na constituição do patrimônio. Além disso, entende ela que os partícipes das uniões paralelas ainda concorrem com os herdeiros necessários no que tange aos aludidos bens adquiridos na constância do convívio.

Interessante raciocínio trazido pela aludida autora diz respeito a uma das consequências indiretas do não reconhecimento de direito sucessório às relações paralelas. É que como a Constituição Federal não admite mais tratamento discriminatório dos filhos, ao se negar à mãe os direitos decorrentes da união paralela que a mesma manteve

dade marcada pela existência de relações líquidas, fluidas, de fragilidade ímpar, impõe ao Juiz uma rigorosa análise de cada lide que apresenta paralelismo afetivo, de acordo com as peculiaridades multifacetadas apresentadas no caso concreto, sem aplicar, jamais, raciocínios distanciados da dimensão específica alcançada pelas circunstâncias contextuais do processo. 7. A inexistência da prova de patrimônio adquirido pelo esforço comum é circunstância suficiente para afastar a configuração de sociedade de fato, porque é pressuposto para seu reconhecimento. 8. Desse modo, a simples convivência sob a roupagem de concubinato não confere direito ao reconhecimento de sociedade de fato, que somente emerge diante da efetiva comprovação de esforço mútuo despendido pelos concubinos para a formação de patrimônio comum. Isso porque a existência de sociedade de fato pressupõe, necessariamente, a aquisição de bens ao longo do relacionamento, para que se possa ter por caracterizado o patrimônio comum. 9. A pertinência dessa construção jurisprudencial deve ser firmemente estabelecida, com vistas a salvaguardar as partes da malícia e da má-fé, por meio da utilização de premissas falaciosas de argumentos que possam inverter o sentido e a intenção das criações do Direito, as quais seguem sempre no rastro da realidade social e da preservação dos direitos inerentes à promoção do bem-estar do ser humano. 10. Agravo conhecido para dar provimento ao recurso especial” (Superior Tribunal de Justiça, AgRg no REsp 1170799/PB, Relator Ministro Massami Uyeda, Relatora para o acórdão Ministra Nancy Andrighi, Terceira Turma, julgado em 03/08/2010, DJe 06/12/2010).

96 DIAS, Maria Berenice. Manual das Sucessões. 2. ed., rev., atual. e ampl. São Paulo: Editora Revista dos Tribunais, 2011, p. 90-91. 
é excluir o direito sucessório do filho com relação a ela. Ou seja, deixar de reconhecer o direito da mãe, pela via inversa e reflexamente, é não reconhecer o direito que o filho teria à herança dela. ${ }^{97}$

A hipótese de participação do integrante supérstite da relação paralela na herança deixada já foi reconhecida em julgados do Tribunal de Justiça do Rio Grande do Sul ${ }^{98}$.
A segunda questão relevante que vem merecendo pronunciamento dos Tribunais diz respeito à possibilidade de concessão de pensão por morte ao sobrevivente de uma relação paralela. Mais uma vez, o posicionamento atual do Superior Tribunal de Justiça ${ }^{99}$ e predominante do Tribunal de Justiça do Rio Grande do Sul ${ }^{100}$ é no sentido de não se reconhecer o referido direito à pensão, podendo ser encontradas,

97 DIAS, Maria Berenice. Manual de Direito das Famílias. 7. ed., rev., atual. e ampl. São Paulo: Editora Revista dos Tribunais, 2010, p. 51.

98 Como exemplo: “APELAÇÃO. UNIÃO ESTÁVEL CONCOMITANTE AO CASAMENTO. POSSIBILIDADE. DIVISÃO DE BEM. TRIAÇÃO. Viável o reconhecimento de união estável paralela ao casamento. Precedentes jurisprudenciais. Caso em que a prova dos autos é robusta em demonstrar que a apelante manteve união estável com o falecido, mesmo antes de ele se separar de fato da esposa. Necessidade de dividir o único bem adquirido no período em que o casamento foi concomitante à união estável em três partes. Triação. Precedentes jurisprudenciais. DERAM PROVIMENTO, POR MAIORIA” (Tribunal de Justiça do RS, Apelação Cível n. 70024804015, Oitava Câmara Cível, Relator Rui Portanova, julgado em 13/08/2009).

99 Corroborando as decisões proferidas no AgRg no REsp 968.572/RN, no AgRg no Ag 1249035/MG, no AgRg no Ag 683.975/RS e no REsp 1104316/RS, transcreve-se ementa de recentíssimo julgado acerca da questão: “ADMINISTRATIVO. PROCESSUAL CIVIL. AÇÃO DE RECONHECIMENTO DE CONCUBINATO. EXTENSÃO DA RES JUDICATA À ADMISSÃO DE UNIÃO ESTÁVEL. IMPOSSIBILIDADE. LIMITES OBJETIVOS DA COISA JULGADA. PEDIDO E CAUSA DE PEDIR. SERVIDOR PÚBLICO ESTADUAL FALECIDO. PENSÃO POR MORTE. RATEIO ENTRE VIÚVA E CONCUBINA. IMPOSSIBILIDADE. PRECEDENTES. [...] 5. O reconhecimento da união estável pressupõe a inexistência de impedimentos para o casamento. 6. A vigência de matrimônio não é empecilho para a caracterização da união estável, desde que esteja evidenciada a separação de fato entre os ex-cônjuges, o que não é a hipótese dos autos. 7. O concubinato não pode ser erigido ao mesmo patamar jurídico da união estável, sendo certo que o reconhecimento dessa última é condição imprescindível à garantia dos direitos previstos na Constituição Federal e na legislação pátria aos companheiros, inclusive para fins previdenciários. 8. Recurso ordinário em mandado de segurança conhecido e provido (Superior Tribunal de Justiça, RMS 30.414/PB, Relatora Ministra Laurita Vaz, Quinta Turma, julgado em 17/04/2012).

100 Vide, como exemplo, acórdão n. 70046287843. 
neste último, todavia, algumas decisões em sentido contrário ${ }^{101}$.

Quanto ao recebimento de seguro de vida pelo integrante sobrevivente da união paralela, há dois julgados do Superior Tribunal de Justiça em que, embora ressalvado expressamente que em regra é vedada a designação do concubino como beneficiário do seguro de vida do falecido ${ }^{102}$, tal direito foi concedido em face das peculiaridades do caso concreto ${ }^{103}$. Há também julgado do Tribunal de Justiça do Rio Grande do Sul reconhecendo tal direito ${ }^{104}$.

101 Vide, como exemplo, acórdão n. 70012696068.

102 Direito civil. Recursos especiais. Contratos, família e sucessões. Contrato de seguro instituído em favor de companheira. Possibilidade. - É vedada a designação de concubino como beneficiário de seguro de vida, com a finalidade assentada na necessária proteção do casamento, instituição a ser preservada e que deve ser alçada à condição de prevalência, quando em contraposição com institutos que se desviem da finalidade constitucional. - A união estável também é reconhecida constitucionalmente como entidade familiar; o concubinato, paralelo ao casamento e à união estável, enfrenta obstáculos à geração de efeitos dele decorrentes, especialmente porque concebido sobre o leito do impedimento dos concubinos para o casamento. - Se o Tribunal de origem confere à parte a qualidade de companheira do falecido, essa questão é fática, e posta no acórdão é definitiva para o julgamento do recurso especial. - Se o capital segurado for revertido para beneficiário licitamente designado no contrato de seguro de vida, sem desrespeito à vedação imposta no art. 1.474 do CC/16, porque instituído em favor da companheira do falecido, o instrumento contratual não merece ter sua validade contestada. - Na tentativa de vestir na companheira a roupagem de concubina, fugiram as recorrentes da interpretação que confere o STJ à questão, máxime quando adstrito aos elementos fáticos assim como descritos pelo Tribunal de origem. Recursos especiais não conhecidos (Superior Tribunal de Justiça, REsp 1047538/RS, Relatora Ministra Nancy Andrighi, Terceira Turma, julgado em 04/11/2008, DJe 10/12/2008).

103 SEGURO DE VIDA EM FAVOR DE CONCUBINA. Homem casado. Situação peculiar de coexistência duradoura do de cujus com duas famílias e prole concomitante advinda de ambas as relações. Indicação da concubina como beneficiária do benefício. Fracionamento. Inobstante a regra protetora da família, impedindo a concubina de ser instituída como beneficiária de seguro de vida, porque casado o de cujus, a particular situação dos autos, que demonstra "bigamia", em que o extinto mantinha-se ligado à família e concubinária, tendo prole concomitante com ambas, demanda solução isonômica, atendendo-se à melhor aplicação do Direito. Recurso conhecido e provido em parte para determinar o fracionamento, por igual, da indenização secundária (Superior Tribunal de Justiça, REsp 100.888/BA, Relator Ministro Aldir Passarinho Junior, julgado em 12/3/2000).

104 Ementa: AÇÃO DE CONSIGNAÇÃO. SEGURO DE VIDA. CONCUBINA BENEFICIÁRIA. PROVA DA RELAÇÃO. REVELIA. EFEITOS. MATÉRIA DE FATO. Dúvida a quem pagar, decorrente de alteração das beneficiárias no contrato de seguro 
O Código Civil não confere direito real de habitação ao concubino (aliás, como é sabido, há divergência inclusive se tal direito se aplica às uniões estáveis). No entanto, há interessante julgado do Tribunal de Justiça do Distrito Federal ${ }^{105}$ que, analisando o caso concreto, concede tal direito ao concubino sobrevivente ${ }^{106}$.

Por fim, no tocante à possibilidade de a concubina ser eleita como legatária, há, como visto anteriormente, regulamentação expressa no art. 1.801 do Código Civil, no sentido de que o concubino do testador casado não pode ser nomeado herdeiro nem legatário (salvo se este, sem culpa sua, estiver separado de fato do cônjuge há mais de cinco anos). Tal norma tem o claro objetivo de proteger o patrimônio conjugal. Em julgado isolado sobre

de vida, estipulando a concubina como beneficiária, no lugar da esposa. Revelia da ré/ concubina. Os efeitos da revelia se operam quanto aos fatos alegados, sendo a presunção, no entanto, relativa. Prova nos autos de que o segurado conviveu durante todo o tempo com a esposa, não elidida pela ré/ concubina. A concubina somente terá direito à indenização securitária, decorrente de seguro de vida, se ficar provado que o segurado estava separado de fato ou se estava ligado à família legítima e concubinária, ao mesmo tempo. Apelo provido. (Tribunal de Justiça do RS, Apelação Cível n. 70009733551, Quinta Câmara Cível, Relator Umberto Guaspari Sudbrack, julgado em 14/10/2004).

105 Embora o foco do trabalho seja a jurisprudência gaúcha e dos Tribunais Superiores, em face da não localização de julgado nesses tribunais, invoca-se, nesse tocante, decisão do Tribunal de Justiça do Distrito Federal.

106 APELAÇÃO CÍVEL DIREITO CIVIL E PROCESSUAL CIVIL. IMISSÃO DE POSSE. DIREITO À POSSE DA VIÚVA [MEEIRA] VERSUS DIREITO REAL DE HABITAÇÃO DA CONCUBINA. PECULIARIDADE DO CASO CONCRETO: ART. 227, § 6 ${ }^{\circ}$, DA CF/88. I - A ação de imissão de posse tem natureza jurídica petitória, pela qual o direito à posse decorre do direito de sequela conferido ao proprietário. II - O reconhecimento judicial da união estável depende da presença de três requisitos fundamentais: fidelidade, notoriedade e affectio maritallis [art. $1^{\circ}$ da Lei n. 9.278/96 c/c art. 1.723 do novo Código Civil]. III - O direito real de habitação é reconhecido na união estável [Lei n. 9.278/96, art. $7^{\circ}$, parágrafo único]. A ele não faz jus a concubina de homem casado que durante vinte e nove anos manteve duas famílias, com ela [concubina] e com a esposa. IV - Excepcionalmente, pela peculiaridade do caso concreto, mantêm-se a concubina e os filhos do de cujus no imóvel do qual é meeira a viúva em homenagem ao disposto no art. 227, § $6^{\circ}$, da Carta Política de 1988, que consagra a proteção à família e aos filhos havidos fora do casamento (Tribunal de Justiça do DF, Apelação Cível n. 20020310161859, Segunda Câmara Cível, Relator Waldir Leôncio Junior, julgado em 19/08/2004). 
a matéria no Tribunal de Justiça do Rio Grande do Sul, confirmou-se tal vedação $0^{107}$. Vale referir a crítica existente ao referido dispositivo, uma vez que, a partir da separação de fato, não há óbice legal para a constituição de uma união estável (desde que, é claro, preenchidos os requisitos para tanto), não havendo necessidade para o lapso temporal de cinco anos.

Assim, são diversos os aspectos que decorrem do falecimento de um dos integrantes da união paralela. Não se pretendeu exaurir aqui - e nem seria possível - todos os questionamentos que decorrem de tal situação, mas, sim, demonstrar o posicionamento atual da jurisprudência acerca das questões que vêm sendo com maior frequência objeto de discussão judicial.

\section{CONSIDERAÇÕES FINAIS}

Não há dúvidas de que estamos diante de uma nova família: a família constitucional. O afeto, a solidariedade e a dignidade de seus entes cons- tituem-se elementos essenciais para a formação e consolidação dessa nova instituição. Protege-se o objeto da relação e minimiza-se a forma.

Todavia, mesmo que presentes todos esses elementos, ainda são muitas as controvérsias existentes quanto ao reconhecimento de algumas relações como entidades familiares. Seja pela subjetividade de um de seus elementos precípuos - afeto -, seja pela eventual afronta a modelos e princípios ainda existentes em nossa sociedade, uniões paralelas ainda não tem seu lugar definido no mundo jurídico.

Há que se ter uma constante preocupação para que o conceito jurídico de afeto não seja "vulgarizado". Nem todo sentimento entre duas pessoas é afeto. E nem todo afeto é relevante para o direito. Entre situações extremas em que a existência ou não de afeto se mostra evidente, há uma cortina de fumaça que não nos permite distinguir com exatidão que sentimento é esse capaz de formar um verdadeiro núcleo familiar.

Outrossim, não há como eliminar, de um dia para o outro, costumes e

107 APELAÇÃO CÍVEL. SUCESSÕES. AÇÃO DE ANULAÇÃO DE CLÁUSULA DE TESTAMENTO. LEGATÁRIA CONCUBINA. Apesar de toda a prova trazida aos autos acerca da relação entre o testador e a legatária, a natureza do relacionamento já foi delimitada em demanda transitada em julgado. Assim, definida a relação como adulterina, a disposição de última vontade encontra óbice no inciso III do artigo 1.801 do Código Civil. NEGARAM PROVIMENTO AO APELO (Tribunal de Justiça do RS, Apelação Cível Nº 70036759421, Oitava Câmara Cível, Relator Alzir Felippe Schmitz, julgado em 04/08/2011). 
princípios que ainda regem a sociedade. Não se pode olvidar que é a sociedade quem dá os subsídios necessários para que o Legislativo e o Judiciário elaborem e apliquem as leis. O regramento jurídico e as decisões judiciais não podem impor à sociedade o que por ela ainda não é aceito.

Será que uma relação afetiva constituída ante o possível - e provável - desmantelamento de uma outra relação afetiva já existente obedece a princípios éticos, morais e aos bons costumes? Será que a infidelidade já é aceita pela sociedade? Será que a monogamia pode ser considerada um princípio jurídico vigente? A reflexão sobre tais questionamentos nos parece fundamental para formação de um posicionamento sobre o tema. Trata-se de questão de tamanha complexidade, que parece não haver solução verdadeiramente justa.

Parece certo, no entanto, que diante da realidade social e jurídica atual, devem ser afastados dois posicionamentos radicais. De um lado, mostra-se descabido negar-se todo e qualquer direito patrimonial às relações concubinárias (inclusive no campo obrigacional), pois, assim, estar-se-á contrariando as regras mais elementares do ordenamento jurídico, como a que veda o enriquecimento sem causa. De outro lado, não se pode simplesmente equiparar as relações paralelas a uma união estável propriamente dita, seja porque esta não foi a intenção do legislador, seja porque a infidelidade contraria os costumes ainda enraizados da sociedade brasileira, seja em razão do princípio da segurança jurídica, seja, ainda, porque a monogamia trata-se de princípio que ainda está vigente em nosso ordenamento jurídico (reconhecido como tal também em outros países de mesma cultura, como a Argentina ${ }^{108}$ ), merecendo ser considerado.

Como regra, na esteira do que vem entendendo a doutrina e a jurisprudência majoritárias, a solução dos conflitos envolvendo relações paralelas deve ser buscada no direito das obrigações, a fim de se evitar o enriquecimento sem causa.

No entanto, dada a complexidade das questões envolvidas, a melhor solução passa, necessariamente, pela análise do caso concreto, devendo ser ponderados todos os princípios envolvidos (tais como o da dignidade da pessoa humana, o da segurança jurídica, o da monogamia e o da

108 "El deber de fidelidade es recíproco, absoluto e incompensable y permanente. [...] El deber de fidelidade no solo compreender el débito conyugal, sino que es mucho más amplio, comprendiendo conductas diferentes a las relaciones sexuales" (LLOVERAS, Nora. El derecho de familia desde la Constitucion Nacional. 1. ed. Buenos Aires: Universidad, 2009, p. 280). 
boa-fé), sendo possível, em situações excepcionais, reconhecer a existência de uma união estável paralela ao casamento ou a uma outra união estável. É o caso, por exemplo, em que está presente uma legítima expectativa do objetivo de constituir família (requisito para configuração de união estável), consubstanciado no desconhecimento acerca de impedimento do outro integrante da relação de contrair matrimônio ou constituir união estável. Certamente haverá outras situações em que se mostrará inevitável o reconhecimento de amplos efeitos jurídicos às relações paralelas.

\section{REFERÊNCIAS}

ALMEIDA, Renata Barbosa de; RODRIGUES JÚNIOR, Walsir Edson. Direito Civil: Famílias. Rio de Janeiro: Lumen Juris, 2010.

AZEVEDO, Álvaro Villaça. Estatuto da Família de Fato. São Paulo: Jurídica Brasileira, 2001.

BARBOSA, Águida Arruda. Conceito Pós-moderno de Família. In: HIRONAKA, Giselda Maria Fernandes Novaes (Coord.); TARTUCE, Flávio (Coord.); SIMÃO, José Fernando (Coord). Direito de Família e das Sucessões: temas atuais. São Paulo: Método, 2009.

BAUMAN, Zygmunt. Amor Líquido: sobre a fragilidade dos laços humanos. Rio de Janeiro: Jorge Zahar, 2004.

- Modernidade líquida. Tradução de Plínio Dentzien. Rio de Janeiro: Jorge Zahar Editor, 2001. BORGHI, Hélio. Casamento \& União Estável: formação, eficácia e dissolução. São Paulo: Editora Juarez de Oliveira, 2005.
BOSSERT, Gustavo A.; ZANNONI, Eduardo A. Manual de derecho de familia. 6. ed. actual. y ampl. Buenos Aires: Depalma, 2004.

CAHALI, Francisco José (Coord.); PEREIRA, Rodrigo da Cunha (Coord.). Alimentos no Código Civil: aspectos civil, constitucional, processual e penal. São Paulo: Saraiva, 2005.

CAHALI, Yussef Said. Dos alimentos. 6. ed., rev., atual. e ampl. São Paulo: Editora Revista dos Tribunais, 2009.

CARBONERA, Silvana Maria. O papel jurídico do afeto nas relações de família. In: FACHIN, Luiz Edson (Org.). Repensando fundamentos do Direito Civil brasileiro contemporâneo. Rio de Janeiro: Renovar, 1998.

CAVALCANTI, Lourival Silva. União estável: a inconstitucionalidade de sua regulamentação. São Paulo: Saraiva, 2003.

DIAS, Maria Berenice. Manual das Sucessões. 2. ed., rev., atual. e 
ampl. São Paulo: Editora Revista dos Tribunais, 2011.

- Manual de Direito das Famílias. 7. ed., rev., atual. e ampl. São Paulo: Editora Revista dos Tribunais, 2010.

FACHIN, Luiz Edson. Direito de família: elementos críticos à luz do novo código civil brasileiro. 2. ed. Rio de Janeiro: Renovar, 2003.

FACHINI NETO, Eugênio. Reflexões histórico-evolutivas sobre a constitucionalização do direito privado. In: SARLET, Ingo Wolfang (Org.). Constituição, direitos fundamentais e direito privado. 2. ed. Porto Alegre: Livraria do Advogado, 2006.

FARIAS, Cristiano Chaves de. Escritos de Direito de Família. Rio de Janeiro: Editora Lumen Juris, 2007.

FARIAS, Cristiano Chaves de; ROSENVALD, Nelson. Direito das famílias. Rio de Janeiro: Lumen Juris, 2008.

FEITOSA, Maria Luiza Pereira de Alencar Mayer. Concubinato e união estável. Jus Navigandi, Teresina, ano 5, n. 45, 1 set. 2000. Disponível em: <http://jus.com. br/revista/texto/545>. Acesso em: 3 ago. 2012.

FIUZA, Ricardo (Coord.). Novo Código Civil Comentado. São Paulo: Saraiva, 2002.

GIORGIS, José Carlos Teixeira. Direito de família contemporâneo.
Porto Alegre: Livraria do Advogado Editora, 2010.

HIRONAKA, Giselda Maria Fernandes Novaes (Coord.); TARTUCE, Flávio (Coord.); SIMÃO, José Fernando (Coord). Direito de Família e das Sucessões: temas atuais. São Paulo: Método, 2009.

HIRONAKA, Giselda Maria Fernandes Novaes. Direito Sucessório e Constituição: Controvérsias e Tendências. In: HIRONAKA, Giselda Maria Fernandes Novaes (Coord.); TARTUCE, Flávio (Coord.); SIMÃO, José Fernando (Coord). Direito de Família e das Sucessões: temas atuais. São Paulo: Método, 2009.

- Família e casamento em evolução. In: Direito civil: estudos. Belo Horizonte: Del Rey, 2000.

JAYME, Erik. Direito Internacional Privado e Cultura Pós-Moderna. Tradução de Lisiane Feiten Wingert, revisão de Cláudia Lima Marques. Cadernos do Programa de Pós-Graduação em Direito PPGDir/UFRGS, Porto Alegre, v. 1, n. 1, mar. 2003. 2. ed., 3. Tiragem, dez. 2004.

LEITE, Eduardo de Oliveira. Direito das Sucessões. In: TEIXEIRA, Sálvio de Figueiredo (Org.). Direito Civil Aplicado. 2. ed. São Paulo: Revista dos Tribunais, 2012.

LLOVERAS, Nora. El derecho de familia desde la Constitucion Na- 
cional. 1. ed. Buenos Aires: Universidad, 2009.

LÔBO, Paulo Luiz Netto. Direito civil: famílias. 4. ed. São Paulo: Saraiva, 2011

MADALENO, Rolf. Curso de direito de familia. 4. ed., rev., atual. e ampl. Rio de Janeiro: Forense, 2011.

MATOS, Ana Carla Harmatiuk. Aspectos jurídicos das famílias homossexual, simultânea e recomposta. In: HIRONAKA, Giselda Maria Fernandes Novaes (Coord.); TARTUCE, Flávio (Coord.); SIMÃO, José Fernando (Coord). Direito de Família e das Sucessões: temas atuais. São Paulo: Método, 2009.

NORONHA, Carlos Silveira (Org.). As Novas Perspectivas do Direito das Sucessões em tempos de modernidade e pós-modernidade. Porto Alegre: Sulina, 2011.

OLIVEIRA, Euclides. União Estável na Jurisprudência do STJ e do STF. In: HIRONAKA, Giselda Maria Fernandes Novaes (Coord.); TARTUCE, Flávio (Coord.); SIMÃO, José Fernando (Coord). Direito de Família e das Sucessões: temas atuais. São Paulo: Método, 2009.

OLIVEIRA, José Sebastião de. Fundamentos constitucionais do direito de família. São Paulo: Editora Revista dos Tribunais, 2003.

PEREIRA, Rodrigo da Cunha. Concubinato e união estável.
8. ed., rev. e atual. São Paulo: Saraiva, 2012.

Princípios fundamentais norteadores do direito de família. Belo Horizonte: Del Rey, 2006.

PEREIRA, Tânia da Silva. Famílias possíveis: Novos paradigmas na convivência familiar. In: PEREIRA, Rodrigo da Cunha (Coord.). Afeto, Ética, Família e o Novo Código Civil. Belo Horizonte: Del Rey, 2004.

PESSOA, Claudia Grieco Tabosa. Efeitos patrimoniais do concubinato. São Paulo: Saraiva, 1997.

QUADROS, Tiago de Almeida. O princípio da monogamia e o concubinato adulterino. Jus Navigandi, Teresina, ano 9, n. 412, 23 ago. 2004. Disponível em: <http:// jus.com.br/revista/texto/5614>. Acesso em: 3 ago. 2012.

RIZZARDO, Arnaldo. Direito das Sucessões: Lei n. 10.406, de 10.01.2022. 5. ed. Rio de Janeiro: Forense, 2009. . Direito de Família: Lei n. 10.406, de 10.01.2002. Rio de Janeiro: Forense, 2009.

RODRIGUES, Silvio. Direito Civil: direito de família. 28. ed. rev. e atual. São Paulo: Saraiva, 2004.

SANTOS, Marília Andrade dos. Meação em razão da extinção de união estável adulterina: estudo de caso. Jus Navigandi, Teresina, ano 11, n. 1252, 5 dez. 2006 . Disponível em: <http://jus.com. 
br/revista/texto/9243>. Acesso em: 3 ago. 2012.

SARLET, Ingo Wolfgang. O Princípio da Dignidade da Pessoa Humana $e$ os Direitos Fundamentais. 2. ed. Porto Alegre: Livraria do Advogado, 2002.

SCHREIBER, Anderson. Família Simultâneas e Redes Familiares. In: HIRONAKA, Giselda Maria Fernandes Novaes (Coord.); TARTUCE, Flávio (Coord.); SIMÃO, José Fernando (Coord). Direito de Família e das Sucessões: temas atuais. São Paulo: Método, 2009.

SILVA, Regina Beatriz Tavares da. Novo Código Civil Comentado: arts. 1.639 a 1.652. In: FIUZA, Ricardo (Coord.). Novo Código
Civil Comentado. São Paulo: Saraiva, 2002.

TEIXEIRA, Ana Carolina Brochado (Coord.); RIBEIRO, Gustavo Pereira Leite (Coord.). Manual de Direito das Famílias e das Sucessões. Belo Horizonte: Del Rey; Mandamentos, 2008.

VELOSO, Zeno. Direito hereditário do cônjuge e do companheiro. São Paulo: Saraiva, 2010.

VENOSA, Sílvio de Salvo. Direito de família. In: Direito civil. V. 6. 6. ed. São Paulo: Atlas, 2006. - Direito de família. In: . Direito civil. V. 6. 11. ed.. São Paulo: Atlas, 2011.

WALD, Arnoldo. O novo direito de família. São Paulo: Saraiva, 2004. 